\title{
A Summary of Information on the Behavior of the Yakima Fold Belt as a Structural Entity
}

\section{Topical Report}

GV Last

$\mathrm{K}$ Winsor

SD Unwin

August 2012

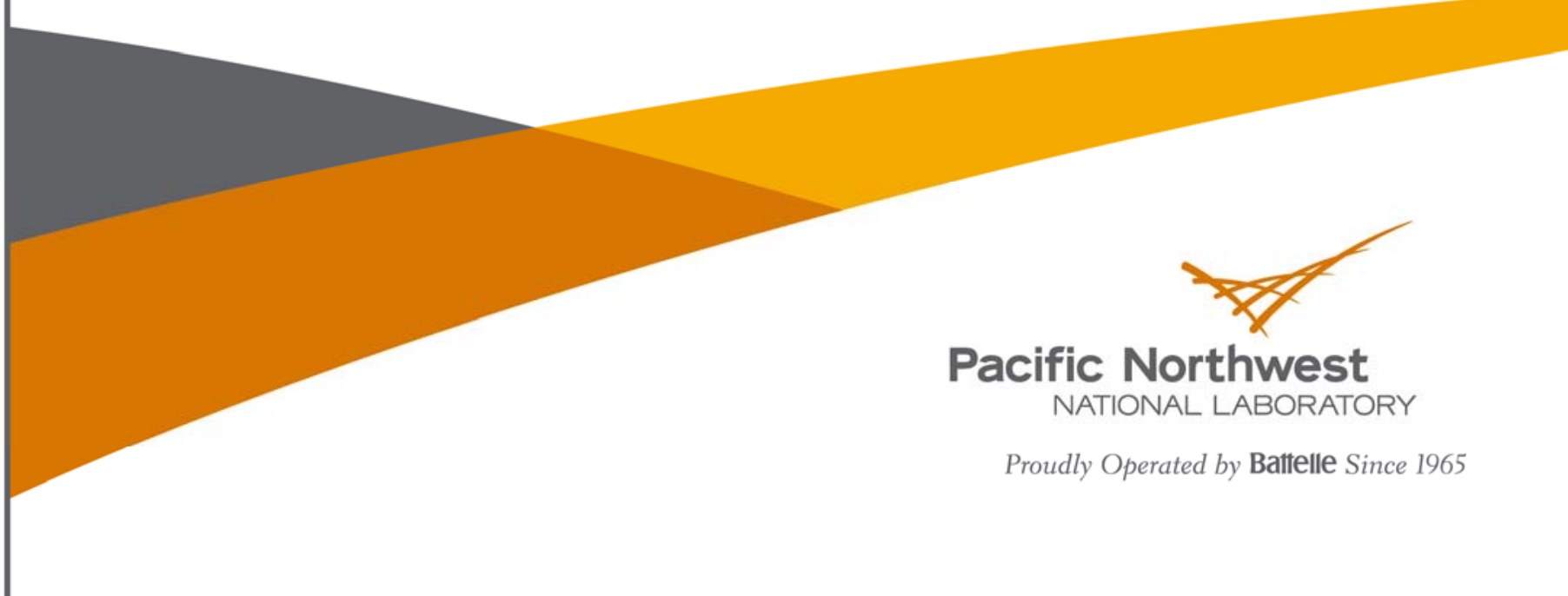




\title{
DISCLAIMER
}

This report was prepared as an account of work sponsored by an agency of the United States Government. Neither the United States Government nor any agency thereof, nor Battelle Memorial Institute, nor any of their employees, makes any warranty, express or implied, or assumes any legal liability or responsibility for the accuracy, completeness, or usefulness of any information, apparatus, product, or process disclosed, or represents that its use would not infringe privately owned rights. Reference herein to any specific commercial product, process, or service by trade name, trademark, manufacturer, or otherwise does not necessarily constitute or imply its endorsement, recommendation, or favoring by the United States Government or any agency thereof, or Battelle Memorial Institute. The views and opinions of authors expressed herein do not necessarily state or reflect those of the United States Government or any agency thereof.

\author{
PACIFIC NORTHWEST NATIONAL LABORATORY \\ operated by \\ BATTELLE \\ for the \\ UNITED STATES DEPARTMENT OF ENERGY \\ under Contract DE-AC05-76RL01830 \\ Printed in the United States of America \\ Available to DOE and DOE contractors from the \\ Office of Scientific and Technical Information, \\ P.O. Box 62, Oak Ridge, TN 37831-0062; \\ ph: (865) 576-8401 \\ fax: $(865) 576-5728$ \\ email: reports@adonis.osti.gov \\ Available to the public from the National Technical Information Service \\ 5301 Shawnee Rd., Alexandria, VA 22312 \\ ph: (800) 553-NTIS (6847) \\ email: orders $a$ ntis.gov <http://www.ntis.gov/about/form.aspx> \\ Online ordering: http://www.ntis.gov
}




\section{A Summary of Information on the Behavior of the Yakima Fold Belt as a Structural Entity}

\section{Topical Report}

GV Last

K Winsor

SD Unwin

August 2012

Prepared for

the U.S. Department of Energy

under Contract DE-AC05-76RL01830

Pacific Northwest National Laboratory

Richland, Washington 99352 



\begin{abstract}
This document is one in a series of three topical reports compiled by the Pacific Northwest National Laboratory to summarize technical information on selected topics important to the performance of a probabilistic seismic hazard analysis of the Hanford Site. The data used to compile this report are based on scientific studies and a search of the literature current through 2008.

The purpose of this report is to summarize available data and analyses relevant to the Yakima Fold Belt (YFB) that may bear on the question of whether or not the YFB behaves as a single seismotectonic province in which activity along one fold structure is representative of behavior along all other fold structures. This topic has met with a fairly high level of contention in the expert community and has the potential to result in significant impacts on an evaluation of seismic hazard at the Hanford Site.

This report defines the alternative conceptual models relevant to this technical issue and the arguments and data that support those models. It provides a brief description of the technical issue and principal uncertainties; a general overview on the nature of the technical issue, along with alternative conceptual models, supporting arguments and information, and uncertainties; and, finally, suggests some possible approaches for reducing uncertainties regarding this issue.
\end{abstract}





\section{Acronyms and Abbreviations}

$\begin{array}{ll}\text { ACM } & \text { alternative conceptual model } \\ \text { BP } & \text { before present } \\ \text { CLEW } & \text { Cle Elum-Wallula deformed zone } \\ \text { CRBG } & \text { Columbia River Basalt Group } \\ \text { DOE-ORP } & \text { U.S. Department of Energy Office of River Protection } \\ \text { GMA } & \text { ground motion attenuation } \\ \text { ka } & \text { kilo-annum; one thousand years ago (age) } \\ \text { kyr } & \text { kiloyear(s); one thousand years (time interval) } \\ \text { LiDAR } & \text { light detection and ranging } \\ \text { Ma } & \text { mega-annum; millions of years before present } \\ \text { NGA } & \text { next generation attenuation (model) } \\ \text { OWL } & \text { Olympic-Wallowa lineament } \\ \text { PNNL } & \text { Pacific Northwest National Laboratory } \\ \text { PSHA } & \text { probabilistic seismic hazard analysis } \\ \text { RAW } & \text { Rattlesnake-Wallula alignment } \\ \text { SSC } & \text { seismic source characterization } \\ \text { SSHAC } & \text { Senior Seismic Hazard Analysis Committee } \\ \text { TI } & \text { technical integrator } \\ \text { TR } & \text { topical report } \\ \text { WFZ } & \text { Wallula fault zone } \\ \text { YFB } & \text { Yakima Fold Belt }\end{array}$





\section{Glossary of Terms}

probability of activity - The probability of activity is the likelihood that a given structure is seismogenic, or active, within the present tectonic regime and will, therefore, localize seismicity above the rates occurring randomly within the region (Geomatrix 1996, p. 3-11). The assessment of activity generally is made based on such factors as association with historical seismicity, evidence for late Quaternary fault displacements, geomorphic evidence for geologically recent deformation, association with neighboring structures showing evidence for Quaternary activity, pre-Quaternary history of deformation, and orientation relative to the present stress field.

CLEW - The Cle Elum-Wallula (CLEW) deformed zone is a segment of the Olympic-Wallowa lineament that passes through the central Yakima Fold Belt (Reidel et al. 1989, p. 248).

coupled model - The coupled model, sometimes referred to as the thick skin model, is one in which the faults coring the Yakima folds are rooted in the basement and extend through the sedimentary layer and into the basalts (Zachariasen et al. 2006), resulting in folding at the surface (Figure G.1).

uncoupled model - The uncoupled model, sometimes referred to as the thin skin model, is one in which faults coring the folds and faults in the basement are completely unconnected to each other structurally and seismically (Figure G.1). Faulting in the basalt does not extend into the basement and vice versa (Zachariasen et al. 2006).

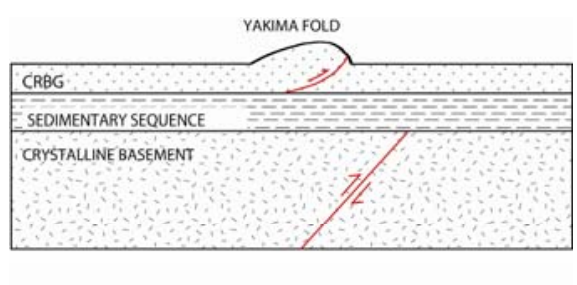

UNCOUPLED MODEL

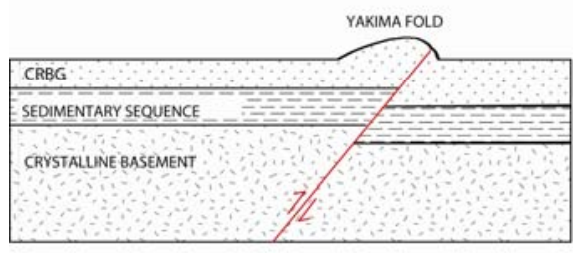

COUPLED MODEL

Figure G.1. Coupled Versus Uncoupled Tectonic Models (after Geomatrix 1996, Figure 2)

décollement - A décollement or detachment fault is a fault in which crustal deformation causes separation along a boundary between rock types, typically between crystalline rock and sedimentary rocks. The décollement horizon acts as a gliding plane between the two masses and often produces a situation where the rocks above the décollement have entirely different structures than the rocks below the fault. 
OWL - The Olympic-Wallowa lineament (OWL) as defined by Raisz (1945) is a pronounced topographic lineament that extends from the northwestern Washington coast (Olympic Peninsula) to along the northeastern "rim" of the Wallowa Mountains in northeastern Oregon (Reidel and Tolan 1994, p. 1).

RAW - The Rattlesnake-Wallula alignment (RAW) is a portion of the Cle Elum-Wallula (CLEW) deformed zone that extends from Rattlesnake Mountain to Wallula Gap and is characterized as a narrow zone of doubly plunging anticlines (Reidel et al. 1989, p. 248).

recurrence interval - The recurrence interval is the average period of time between the occurrence of earthquakes of a given size on a particular fault (Reiter 1990, p.64).

recurrence rate - The recurrence rate is usually expressed as the average number of events greater than or equal to a certain magnitude per unit time. 


\section{Contents}

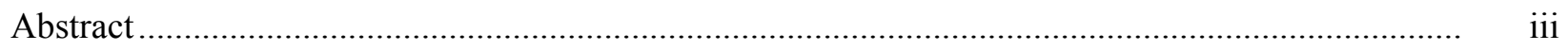

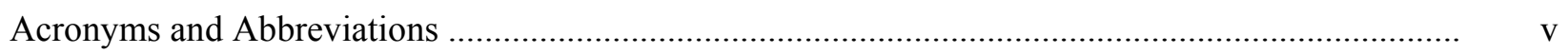

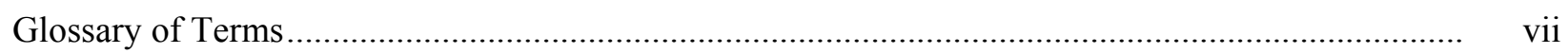

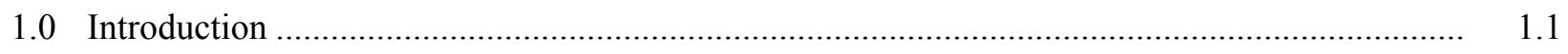

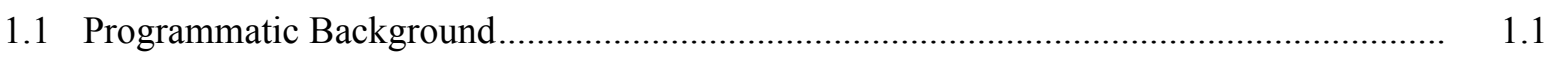

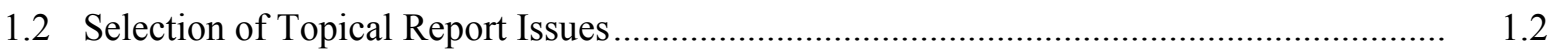

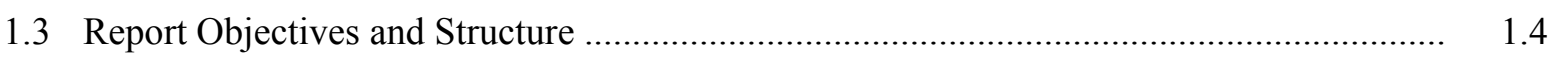

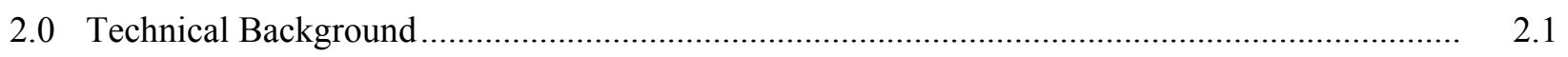

2.1 Structural Similarities and Relationships .............................................................. 2.1

2.2 Similarity in Rate and Timing of Information............................................................. 2.4

2.3 Pattern of Recent Activity ................................................................................... 2.4

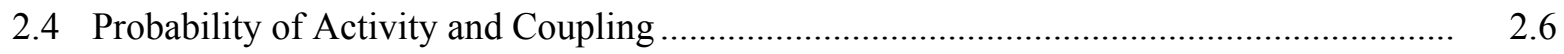

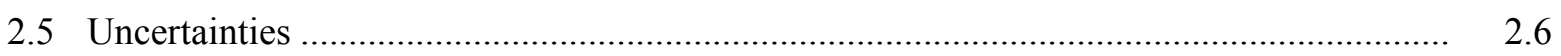

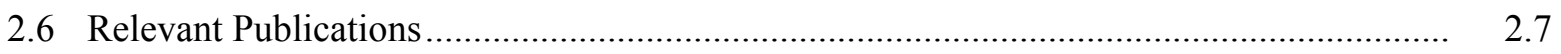

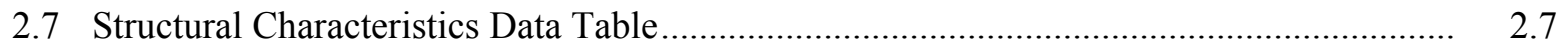

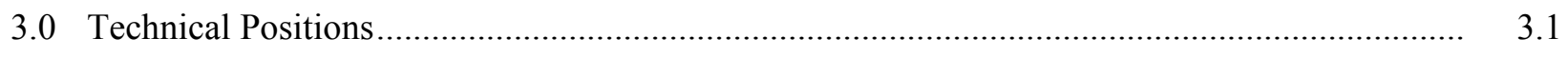

3.1 Alternative Conceptual Model 1 ............................................................................ 3.1

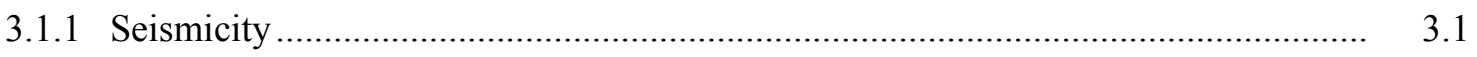

3.1.2 Quaternary Surface Faulting …................................................................. 3.2

3.1.3 Structural Similarity and Interrelationships .................................................... 3.2

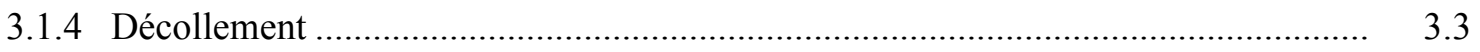

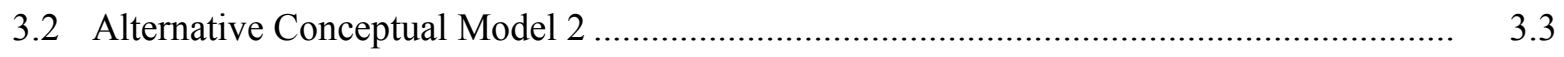

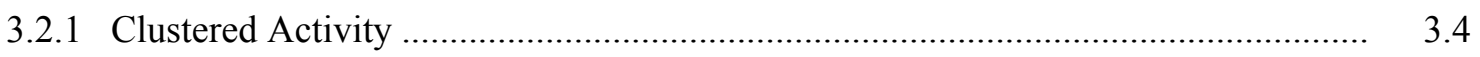

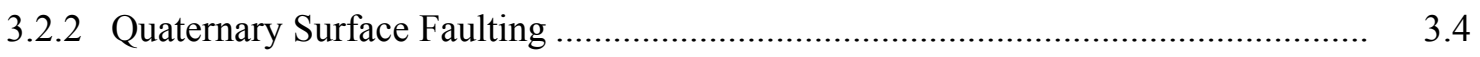

3.3 Alternative Conceptual Model 3 ......................................................................... 3.5

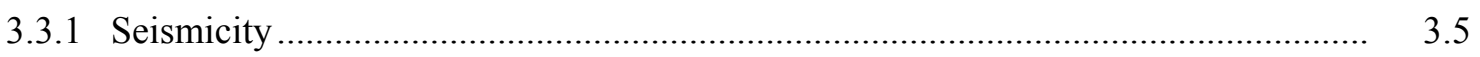

3.3.2 Structural Characteristics and Interrelationships ............................................... 3.5

3.4 Alternative Conceptual Model 4 ........................................................................... 3.6

3.4.1 Ridge Spacing and Orientation................................................................... 3.6

3.4.2 Pre-Basalt Bedrock Features and Coupling..................................................... 3.7

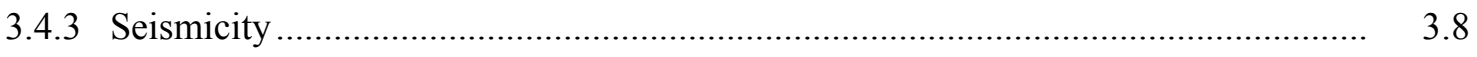

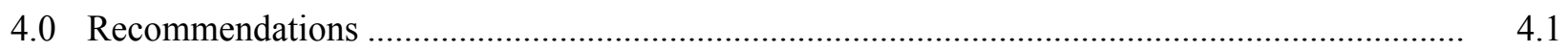

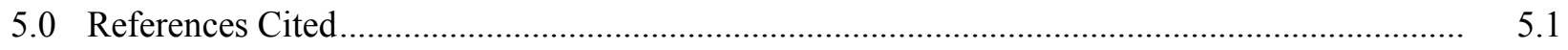

Appendix A - Identification of Topical Reports to Be Prepared for the
Future Hanford Site-Wide Probabilistic Seismic Hazard Analysis ........................................... A.1

Appendix B - Annotated Bibliography ............................................................................. B. 
Appendix C - Summary of Known or Suspected Quaternary Faults

Within the Yakima Fold Belt.

C.1

\section{Figures}

2.1 Major Structural Features in the Columbia Basin.............................................................. 2.2

2.2 Location of the Yakima Fold Belt Subprovince of the Columbia Basin .................................... 2.3

2.3 Generalized North-South Geologic Cross Section Through the Yakima Fold Belt and the

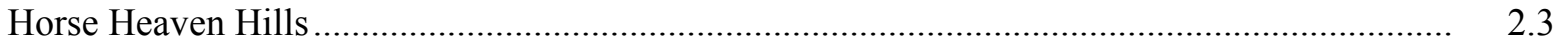

2.4 Cross Section of an Imbricate Fault Fan in New Zealand, Illustrating a Common Basal Sole Thrust Zone or Décollement.

\section{Table}

2.1 Yakima Fold Belt Structures and Associated References..................................................... 


\subsection{Introduction}

This document is one in a series of three topical reports (TRs) compiled by the Pacific Northwest National Laboratory (PNNL). The TRs are intended as technical resources in the performance of a probabilistic seismic hazard analysis (PSHA) of the Hanford Site. The purpose of this report is to summarize available data and analyses relevant to the Yakima Fold Belt (YFB) that may bear on the question of whether or not the YFB behaves as a single seismotectonic province in which activity along one fold structure is representative of behavior along all other fold structures. This topic has met with a fairly high level of contention in the expert community but has the potential to result in significant impacts on an evaluation of seismic hazard at the Hanford Site. The other two TRs address additional technical issues pertinent to a seismic hazard analysis of the Hanford Site, including estimates of fault recurrence and strain rates (Bjornstad et al. 2012) and an evaluation of the coupled versus uncoupled tectonic models proposed for the YFB (Chamness et al. 2012).

\subsection{Programmatic Background}

In any PSHA, there are numerous sources of technical uncertainty. Among such sources are individual technical issues about which the appropriate resolution is uncertain and, often, about which there are opposing viewpoints and contention in the technical community. The Senior Seismic Hazard Analysis Committee (SSHAC) guidance for conducting PSHAs, to which the Hanford study will adhere, recommends that such uncertainties be characterized by the attachment of probabilities to the alternative resolutions of the issues (Budnitz et al. 1997).

These probabilities, which represent so-called epistemic uncertainties - that is, uncertainties reflecting limitations in technical knowledge - can be generated in one of several ways. The SSHAC guidance identifies four alternative bases for generating epistemic probabilities. These alternative methods are denoted as SSHAC Levels 1 through 4, representing increasing degrees of formality and effort. The SSHAC levels selected for the Hanford Site PSHA are

- SSHAC Level 3 for the seismic source characterization (SSC) elements of the analysis

- SSHAC Level 2 for the ground motion attenuation (GMA) modeling elements of the analysis.

The rationale for the selection of these SSHAC levels is documented elsewhere. ${ }^{1}$ For both Level 3 and Level 2 studies, the technical integrator (the TI, where the SSC and GMA elements of the Hanford PSHA each will have its own TI) has ultimate responsibility for development of the epistemic probabilities assigned within each of the technical issues. Per SSHAC guidance, these probabilities must reflect the range of opinions held in the expert technical community. The principal distinction between the Level 3 and Level 2 approaches is that, in the former, the TI assembles a panel of subject matter experts who physically meet to discuss the technical issues for which uncertainties or conflicting opinions exist. This dialog, along with any subsequent communications, provides the basis for the TI to attach the appropriate probabilities to the alternative issue resolutions. In contrast, a Level 2 analysis relies on less formal interactions of the TI with the subject matter experts, generally involving written and telephone communication, based on which the TI formulates the appropriate probabilities.

${ }^{1}$ Draft PSHA Work Plan, June 11, 2007, prepared by Kevin J. Coppersmith, Coppersmith Consulting, for Pacific Northwest National Laboratory under Contract 42259. 
The purpose of the TRs is to provide a convenient encapsulation of technical information about a single technical issue (or family of related issues) of relevance to the PSHA to serve as a resource to the TI and the subject matter experts in their deliberations. The criteria for selection of technical issues for the TRs are described in the next subsection.

The intent of a TR is not to advocate a specific resolution to a technical issue: that is, a TR is not intended to conclude that, despite contention in the technical community, one technical resolution should be preferred to another. Instead, the intent is to present the range of expert opinions and competing technical resolutions and to identify the data and analyses judged within the expert community to support each of these alternative resolutions. Thus, a TR does not advocate a specific viewpoint on the technical matter it expounds but instead is prepared as a convenience for the TI and team by assembling relevant data and analyses upon which they may deliberate.

\subsection{Selection of Topical Report Issues}

The conduct of a PSHA demands that varying degrees of uncertainty about numerous technical issues be addressed and reflected in the seismic hazard model. Uncertainty on the part of a PSHA TI with regard to the appropriate technical resolution of an issue can be the result of one of two situations:

Case 1. There is broad consensus among the technical community that uncertainty exists regarding the appropriate technical resolution of an issue.

Case 2. A range of competing opinions is held within the technical community regarding the appropriate resolution of a technical issue. In this case, any one member of the expert community may strongly favor a particular resolution, and the TI's uncertainty stems from the question of which competing opinion reflects the correct resolution of the issue.

Modeling the uncertainties associated with Case 1 is the more straightforward task because the TI can adopt the consensus view of the expert community. Case 2 is more problematic because the TI is left to evaluate the range of competing opinions and, based upon that evaluation (for SSHAC Level 2 and Level 3 studies), develop a probabilistic characterization of uncertainty for the subject issue. Given that this latter situation is the more challenging for the TI, the TR topics were selected to focus on issues that are defined by Case 2 .

Another discriminating factor in technical uncertainties is the degree to which uncertainty about a specific issue contributes to the resultant uncertainty in the seismic hazard. That is, some technical uncertainties are more important than others with respect to their impact on the results of the PSHA. Therefore, in selecting the issues addressed in the TRs, both the following criteria had to be met:

1. The issue is important to the seismic hazard. That is, the sensitivity of the calculated seismic hazard to the specific resolution of the issue is significant. Equivalently, uncertainty in the appropriate resolution of the issue results in a significant contribution to the total uncertainty in the estimate of the seismic hazard.

2. The correct resolution of the issue is a matter of contention in the expert community. That is, there are opposing schools of thought on the correct resolution, in contrast to a situation in which there is broad agreement that the correct resolution is uncertain. 
As a first step in identifying TR topics, Coppersmith Consulting developed a set of technical issues expected to contribute to uncertainty in the seismic hazard at the Hanford Site. In that analysis, Coppersmith characterized qualitatively (in terms of high, medium, and low categories) each issue with regard to

- its anticipated importance to the hazard; that is, the degree to which it would be expected to contribute to the uncertainty in the seismic hazard - This evaluation was based not on the performance of detailed sensitivity analyses but rather on a limited base of existing sensitivity analyses for the technical issue as well as on the broad experience of the consultant in conducting PSHAs.

- the level of contention within the technical community regarding resolution to the issue.

Both SSC and GMA modeling issues were included in this evaluation. The SSC issue list drew primarily on the technical review by Zachariasen et al. (2006), on behalf of the U.S. Army Corps of Engineers, of the previous PSHA of the Hanford Site (Geomatrix 1996). The list of GMA issues was based on the experience of the consultant Coppersmith and his discussions with ground motion specialists.

Based on this list of issues and the associated assessments of importance and levels of contention, PNNL personnel, supported by Coppersmith and Steve Reidel (a geology consultant with Washington State University), applied the selection criteria described previously to determine which technical issues would be addressed in the TRs. Three issues were identified as meeting the selection criteria, all of which are related to SSC. Although certain GMA issues, such as those associated with the next generation attenuation (NGA) models, were identified as having the potential to have significant impact on uncertainty in the seismic hazard, these issues were not assessed to be sources of significant contention within the expert community. The three SSC issues selected as TR topics were

- whether coupled or uncoupled tectonic models should be used for the Yakima Fold Belt (YFB) - The 1996 PSHA of the Hanford Site (Geomatrix 1996) attached greater weight to the model in which the faults coring the Yakima folds are unconnected to the faults in the basement. This weighting was questioned in the review of the PSHA model by Zachariasen et al. (2006). Chamness et al. (2012) address this issue in their TR.

- whether observation of activity along one Yakima fold structure should be considered an indicator of behavior along all Yakima fold structures - The 1996 PSHA of the Hanford Site (Geomatrix 1996) was based on the assumption that if one fold structure were active, then this did not necessarily imply that all Yakima fold structures were active. The assumption was questioned in the review of the PSHA model by Zachariasen et al. (2006). This issue is addressed in this TR.

- whether the uncertainty ranges in slip rates should be wider than those used in the previous Hanford PSHA, which were based on post-Columbia River Basalt Group ages - This issue was raised in the review of the 1996 PSHA model by Zachariasen et al. (2006). The TR by Bjornstad et al. (2012) addresses this issue.

The second of these technical issues, addressed in this TR, was assessed to have a high level of contention, with up to moderate potential for impact on the hazard estimate (see Appendix A). 


\subsection{Report Objectives and Structure}

The objective of this report is to summarize the range of opinions and supporting information expressed by the expert community regarding whether or not observation of activity along one Yakima fold structure should be considered an indicator of behavior along all Yakima fold structures. This report defines the relevant alternative conceptual models and the arguments and data that support those models.

The remainder of this report is structured as follows. Section 2 provides a brief description of the technical issue and principal uncertainties. Section 3 provides a general overview on the nature of the technical issue, alternative conceptual models, supporting arguments and information, and uncertainties. Section 4 suggests some possible approaches for reducing uncertainties regarding this issue. Section 5 is a listing of the references cited in the main body of this report. Appendix A includes a description of the process and information used to identify the three TRs for preparation by PNNL. Appendix B is an annotated bibliography of literature sources relevant to the YFB issue. Appendix C, provided in electronic format, is an Excel spreadsheet that summarizes data and information on each major structure pertinent to this issue. 


\subsection{Technical Background}

The primary technical issue addressed in this report is the question of ...whether observation of activity along one Yakima fold structure should be considered an indicator of behavior along all Yakima fold structures.

Zachariasen et al. (2006) provide an overview of this technical issue and some of the specific points of contention and uncertainty. The following subsections summarize this information in terms of the structural and tectonic background of the YFB and, where possible, provide general arguments related to alternative conceptual models and uncertainty. Figure 2.1 illustrates the major geologic structures discussed throughout this report as taken from Reidel et al. (1994).

Seismic source characterization (SSC) refers to the component of PSHA in which the locations, size, and frequency of future earthquakes are estimated (Budnitz et al. 1997, p. 51). Evidence for seismogenic activity is often dependent on loosely defined time scales. Some of the lines of evidence or characteristics pertaining to the activity of a fault are its recency of slip, association with seismicity, and structural association with other active faults (NRC 1988). Budnitz et al. 1997, p. 55) suggested that a map of young (Quaternary) faults is judged to provide a stronger basis for defining fault sources in hazard assessment than older (pre-Quaternary) faults. Likewise, the nature and spatial patterns or relationships of instrumental seismicity relative to faults or other seismogenic sources are most important in defining active source areas, while various other types of geologic and structural data may play a lesser role. Note also that the quality of various data can vary significantly.

Most studies of potential seismogenic source areas in the YFB have focused on examining evidence of fault activity during the Quaternary period (1.6 million years to present) and have been biased toward specific structures with at least some degree of geomorphic evidence. Thus, characterization of potential seismic sources away from these study areas requires additional judgment regarding the tectonic model and structural relationships between the well-studied and poorly studied areas. Piety et al. (1990, p. 9) suggest that although uplift on an anticline is probably accompanied by down-dropping of adjacent synclines, only anticlines have been documented to have associated seismogenic faults. Thus, synclines in the YFB are not discussed as separate seismic sources. The following discussion summarizes some of the concerns and uncertainties regarding how potential seismic source areas should be identified and characterized.

\subsection{Structural Similarities and Relationships}

Myers and Price (1979, p. II-72) identified the YFB as a structural subprovince of the Columbia Plateau, characterized by linear anticlines and broad synclines extending generally eastward from the Cascade Range (Figure 2.2). Zachariasen et al. (2006) further described the fold belt as a "kinematically consistent, structurally associated group of regionally coherent structures forming a seismotectonic province" and supported that by suggesting "the structures constituting the belt are structurally and tectonically similar, differing more in the age of the most recent earthquake than in fundamental character." They further suggested that similarities in the structural signature and vergence of individual folds (except for the Columbia Hills structure), with their primarily south-dipping imbricate thrusts and north-verging anticlines, indicate that the fold belt is a coherent tectonic region accommodating strain in 
the Miocene-to-current north-south compressive stress regime. Reidel et al. (1989) also suggest that while there are some exceptions (e.g., along the Rattlesnake-Wallula alignment [RAW] or Smyrna Bench segment of the Saddle Mountains), the anticlinal ridges, particularly in the east-central portion of the fold belt, typically display similar structure, with steeply dipping to overturned northern limbs and gently dipping southern limbs (Figure 2.3).

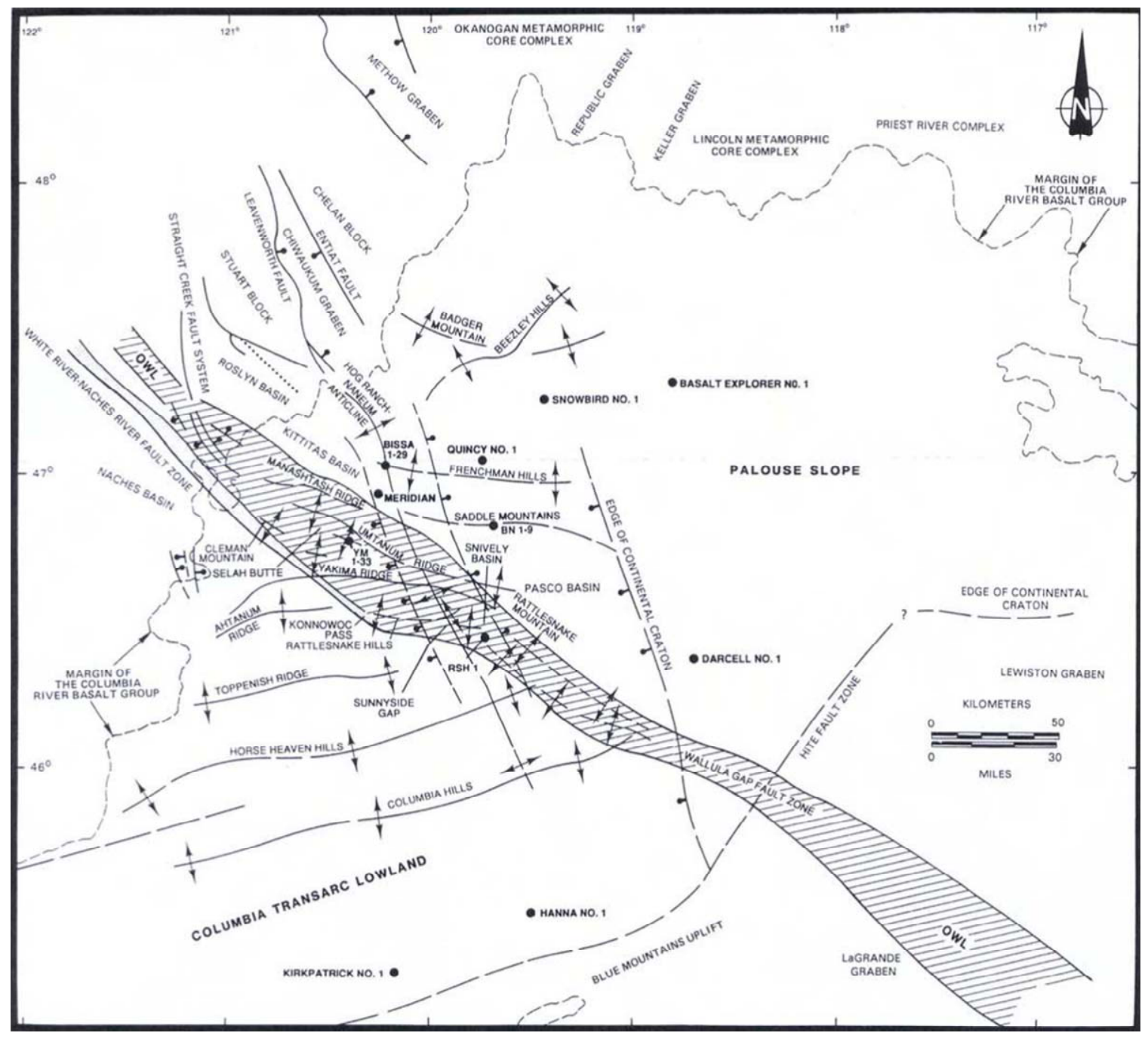

Figure 2.1.Major Structural Features in the Columbia Basin (from Reidel et al. 1994, p. 163)

Campbell and Bentley (1981) suggest that all YFB folds may be structurally connected by a décollement somewhere above the basement rocks. Additionally, Miner (2002) maintains that this décollement is likely 5-12 km deep. However, Beanland and Berryman (1989) suggest that although processes acting on all folds may be the same, stresses may be concentrated in any specific fold for a period of time. Therefore, despite structural similarity or continuity deep within the basalt or into the prebasalt sedimentary rocks, individual structures may be influenced by different processes and individual faults will behave differently at a given time. 


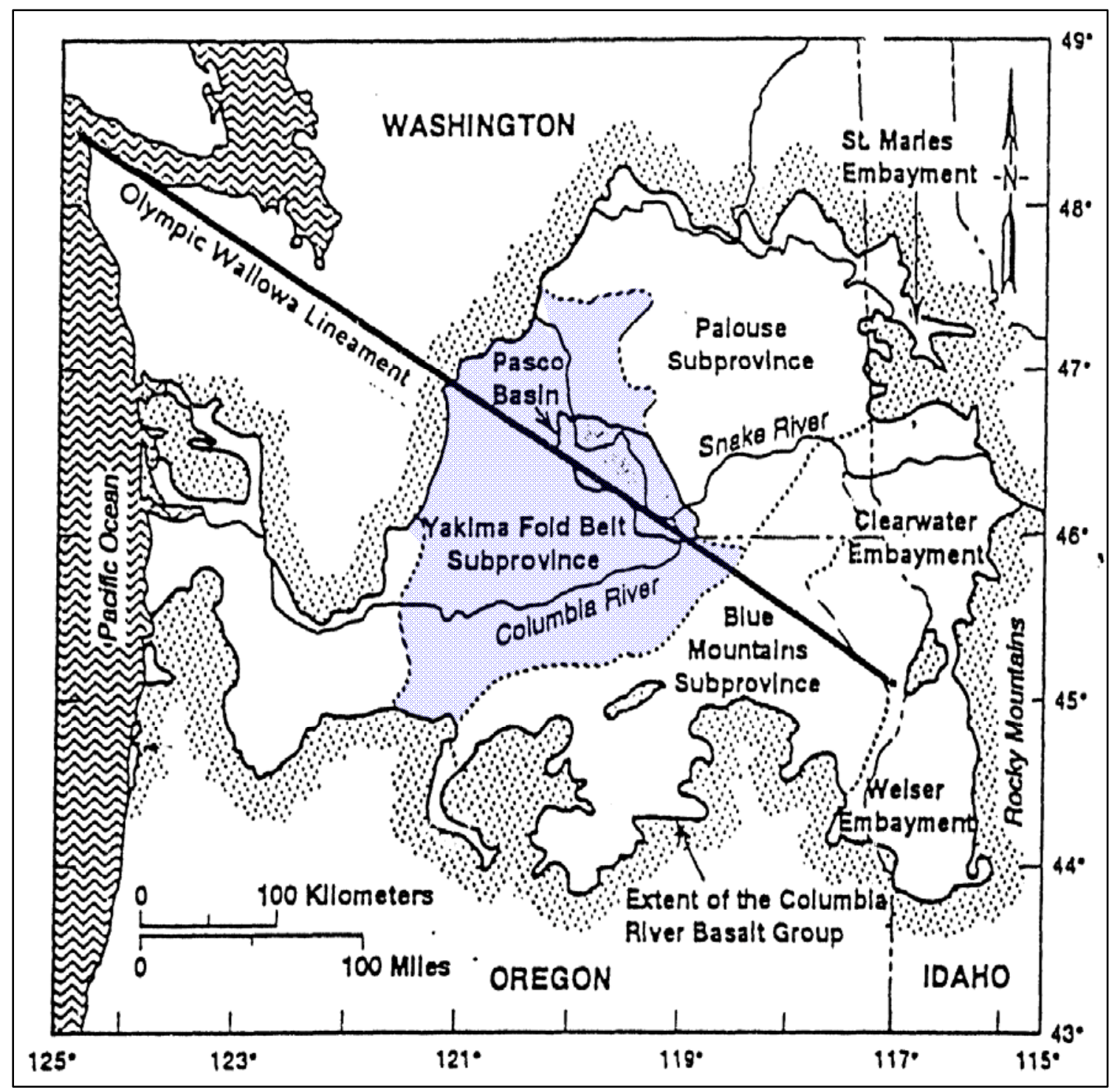

Figure 2.2. Location of the Yakima Fold Belt Subprovince of the Columbia Basin (from Reidel et al. 1994, p. 160)

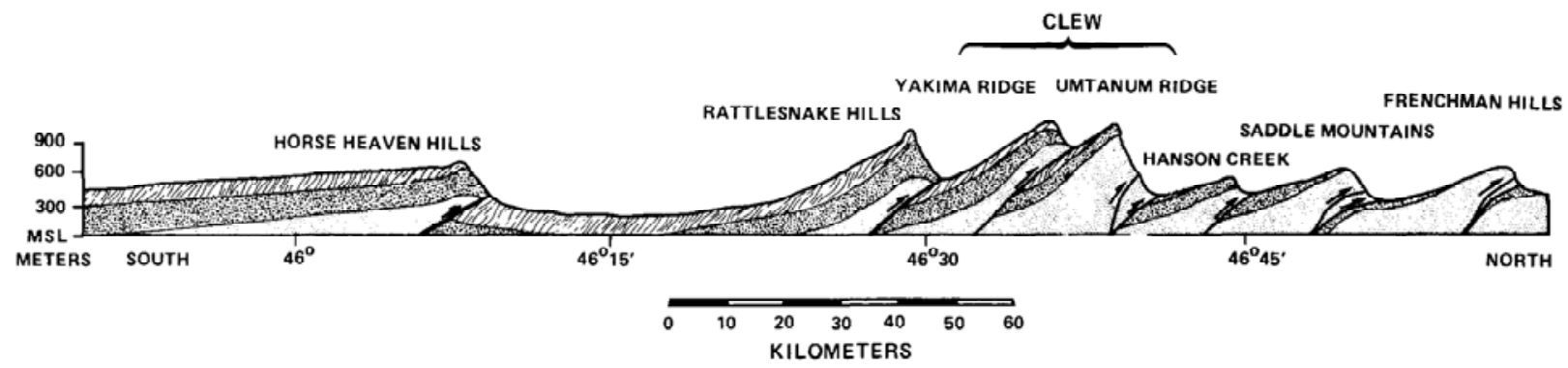

Figure 2.3. Generalized North-South Geologic Cross Section Through the Yakima Fold Belt and the Horse Heaven Hills (from Reidel et al. 1989) 
If the YFB folds are "uncoupled" from the basement rocks by a décollement, there should be no structural continuity between faults (and folds) within the Columbia River Basalt Group (CRBG) and those in the basement (Geomatrix 1996, p. 3-13). However, many of the major ridges in the YFB (e.g., Columbia Hills, Horse Heaven Hills, and Rattlesnake Hills) change trend or terminate as they encounter the Olympic-Wallowa lineament (OWL) (Reidel et al. 1989; Piety et al. 1990, p. 27). The fact that the OWL, which is in the basement, affects the Yakima folds suggests a structural link between them and argues against a model in which the folds do not "feel" the basement and vice versa (Zachariasen et al. 2006, p. 2-5). Zachariasen et al. (2006, p. 2-5) also cite several studies that identify other deep structures that affect the CRBG. These deep structures include the Hog Ranch-Naneum Ridge anticline in pre-CRBG rocks (Campbell 1989; Tabor et al. 1982), the Taneum Lake anticline and fault (Tabor et al. 1982; Campbell 1988), the Leavenworth fault system (Campbell 1988), and the White River fault zone (Tabor et al. 2000). Locations where interaction with deep structures may result in additional stresses include the eastern edge of the Saddle Mountains Ridge as it dies out over the continental craton (Tolan et al. 2004) and the Frenchman Hills and Saddle Mountains-Manastash Ridge where they cross the Hog Ranch-Naneum Ridge anticline. These potential connections indicate that even if one set of stresses may be acting on all the YFB folds and even if these folds are decoupled, coincident relationships with nearby or adjacent structures may cause variations in the magnitude or direction each fold experiences.

\subsection{Similarity in Rate and Timing of Information}

Geomatrix (1996) suggested that similar rates and timing of CRBG deformation (over millions of years) indicate essentially contemporaneous (on the scale of millions of years) development of the entire fold belt. Additionally, Zachariasen et al. (2006) suggested that even if the deformation rates vary between structures, there is no reason to think that the fold belt does not behave as a unified structural province and that individual structures within the belt are no longer active.

\subsection{Pattern of Recent Activity}

Zachariasen et al. (2006) suggested that because all YFB faults and folds are part of a single fold belt, it is unlikely that only one of the faults (i.e., the Mill Creek fault on Toppenish Ridge) has a high probability of being active and coupled. They further indicated that there was no significant difference between Toppenish Ridge and the other folds, except that Toppenish Ridge may have experienced the most recent activity (a Holocene earthquake). However, DOE-ORP (2002, Table 2, p. 16) recognized that only Toppenish Ridge sits on top of the Simcoe Mountains volcanic field. This association with a volcanic seismic source may in fact distinguish Toppenish Ridge, and perhaps the adjacent Horse Heaven Hills, from the other YFB anticlines (Geomatrix 1996, p. 3-14).

Seven of the ten major anticlines in the YFB show evidence of Quaternary activity that is limited to individual active thrust faults (and frequently related or secondary normal faults which are also active) cutting across single uplifts. These faults include Frenchman Hills fault, Mill Creek fault, Lind Coulee fault, Central Gable Mountain fault, Ahtanum Creek fault, Saddle Mountains fault, Wallula Gap fault, and Goose Hill fault. None of these faults stretches the entire length of any uplift. In fact, the Saddle Mountains fault is confined to the Smyrna Bench segment of the Saddle Mountains anticline, and the Mill Creek fault is exposed in only the Satus Peak segment of Toppenish Ridge. There is also some geomorphic evidence of Quaternary deformation at Yakima Ridge, Umtanum Ridge, and Horse Heaven Hills. 
Zachariasen et al. (2006) argued that although the geomorphic expression at Toppenish Ridge reflects the youngest tectonic activity $(\sim 500$ years BP), it is similar in type to the geomorphic expression found at other folds. They argued further that if Toppenish Ridge has experienced the most recent surface deformation event within a cohesive seismotectonic province, then it may actually present a smaller hazard than the other faults and folds because of its relatively recent stress release.

Zachariasen et al. (2006) stated that folds with similar structures and evidence of repeated late Quaternary activity are distributed geographically throughout the fold belt, which suggests that other folds within the YFB also are active. If evidence for recent activity were concentrated on one edge of the fold belt, those folds might represent the currently active deformation front and the remaining folds would no longer be active. However, Reidel et al. (1994, p. 172) found "There appears to be no pattern of faulting in the YFB that would suggest that Pleistocene-Holocene faulting is more concentrated in one part of the basin than in another. Rather the distribution seems to suggest that the entire fold belt has continued to develop in a pattern similar to that of the Pliocene and Miocene".

The reported age of most recent activity varies considerably (from $\sim 500$ years $\mathrm{BP}$ to $<1.6 \mathrm{Ma}$ ) between YFB structures, which at face value does not support uniformity of the YFB. However, evidence from other tectonic provinces (e.g., Meghraoui et al. 1988; Beanland and Berryman 1989) indicates that periods of clustered seismic activity occur in one fault or set of faults over any specific time interval. Activity is followed by long periods of inactivity in that particular area, while other faults in the province may become active. This implies that recent activity or lack of activity on any one YFB structure cannot imply near-future activity. In fact, Beanland and Berryman (1989) suggest that such a sequential behavior of seismicity supports the structural connection of the region's faults and folds (perhaps linked at depth through a regional crustal décollement zone) (Figure 2.4).

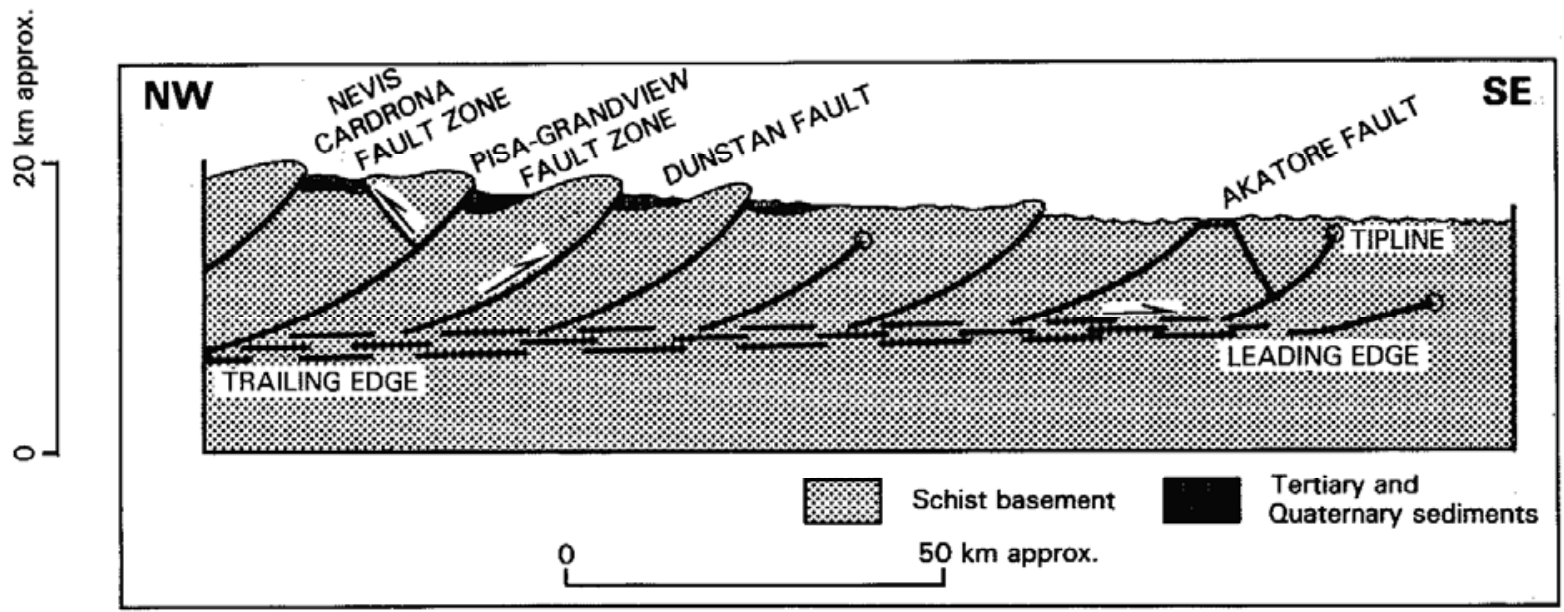

Figure 2.4. Cross Section of an Imbricate Fault Fan in New Zealand, Illustrating a Common Basal Sole Thrust Zone or Décollement. The fault zone would provide a mechanism for transmitting stresses so that for some time, one fault may be active, but later a different fault may accommodate the deformation (from Beanland and Berryman 1989). 


\subsection{Probability of Activity and Coupling}

Zachariasen et al. (2006) found that the details of the Geomatrix (1996) seismic source model did not interpret the YFB as a coherent structural province. Instead, the geometric and behavioral characteristics assigned to individual structures differed greatly from one structure to another and appeared to represent different and separate structures more than related elements of a cohesive structural domain. For example, Geomatrix (1996, p. 3-14) assigned a higher probability of coupling to Toppenish Ridge than they did to other related structures (Horse Heaven Hills NE, Columbia Hills). As the basis for this assessment, they used evidence for large individual-event displacements along Toppenish Ridge (Campbell et al. 1995), with the amount of individual offsets $(-3 \mathrm{~m})$ being indicative of relatively large events and implying significant downdip extent for the associated faults. Geomatrix (1996, p. 3-14) also suggested that the Toppenish Ridge area may be more active than the rest of the Columbia Basin and YFB because it occupies a structural setting that appears to be more influenced by the present Cascade Arc (e.g., the Simcoe Mountains volcanic field). Geomatrix also noted that Toppenish Ridge is on trend with an alignment in the Cascade Range that includes Mt. Adams and Mt. St. Helens.

However, Zachariasen et al. (2006, p. 2-25) cited Walsh et al. (1987) in arguing that field data does not support the uniqueness of Toppenish Ridge's possible penetration into the basement. The presence of the Simcoe volcanic field directly under the CRBG may have also resulted in connection between the basement and both Ahtanum Ridge and Horse Heaven Hills, which are anticlines close to Toppenish Ridge. Zachariasen et al. (2006) further suggest that "Given the history and characteristics of the fold belt, it may be more appropriate to model the fold belt as a unit with the constituent folds having similar behavior in terms of probability of activity and/or coupling. And, given the clear Quaternary activity of several structures widely distributed across the YFB, this may in turn imply that probabilities of activity and/or coupling on the other less studied folds should be given higher weights."

Even if regional tectonic processes within the YFB act similarly on all folds, stresses may be concentrated in one fold or groups of folds and individual faults may behave differently at any given time, similar to faults in New Zealand (Beanland and Berryman 1989). Although a transition from activity to inactivity or vice versa may be impossible to predict, lengths of the active and inactive periods are likely on the order of tens of thousands of years, given the differences in age of most recent deformation within the YFB. It is more likely for the present to fall somewhere within the beginning or middle of these periods, as opposed to within the last few thousand years. Given this, there is a higher probability that activity or inactivity would persist for any individual fault in the near future than there is a likelihood of a change in its activity. This argument depends heavily on the length of time a fault can be expected to remain active or inactive. It also demonstrates that treating the YFB as structurally connected does not necessarily permit all faults to be modeled the same when determining probabilistic seismic hazard. Rather, modeling could split the structures into two groups - those that show recent activity and those that do not.

\subsection{Uncertainties}

A number of uncertainties must be recognized and dealt with, regarding how to model individual folds and other structures within the YFB. Zachariasen et al. (2006) suggest that it may be more appropriate to model the fold belt as a unit with the constituent folds having similar behavior in terms of probability of activity and/or coupling. They also suggest that the evidence of Quaternary activity widely 
distributed across several structures within the YFB implies that probabilities of activity and/or coupling on the other less-studied folds should be given similar weights to those of Toppenish Ridge, Saddle Mountains, and/or Ahtanum Ridge. However, Geomatrix $(1994,1996)$ argue that some structures should be assigned a lower probability of activity than others because there is a lack of definitive evidence for Quaternary deformation and there is a highly uncertain relationship between some YFB structures and others structures such as the Hog Ranch-Naneum Ridge anticline.

Geomatrix (1996) assigned different probabilities of activity, rupture lengths, and downdip widths of faults to different fold structures and suggested that some folds may be coupled to the basement while others are not. Geomatrix (1996) also suggested that the general lack of spatial association of seismicity with faults inferred to underlie the folds may be due to a low rate of observed seismic activity (due to short duration of the observed record), or the folds may not in fact contain seismogenic faults.

Some of the primary points of contention and uncertainty associated with “... whether observation of activity along one Yakima fold structure should be considered an indicator of behavior along all Yakima fold structures" are the following:

- whether structures within the YFB are coupled or uncoupled to basement structures (see Chamness et al. 2012)

- age of the most recent activity - A lack of evidence for this may be due to paucity of data from less well-studied structures, the absence of Quaternary sediments in which to observe and date offset, or unknown age of sediments overlying a fault.

- fault dip and downdip widths, crustal thickness, and depth of detachment zones

- existence, geometries, and association of seismogenic faults with individual fold structures

- extent of similarity in geometry and structural features (structural style, trend, length, amplitude, degree of secondary deformation - e.g., normal faults, segmentation) of different folds and fold segments, and whether similarities necessarily suggest similar behavior

- slip rates on faults underlying the folds, and whether estimates based on fold geometry and rate of growth are adequate.

\subsection{Relevant Publications}

Relevant information to this topical report found in published documents is summarized in Appendix B. No interpretations or judgments were made of the original works by the authors of this topical report, although areas of contention are identified. Although some raw data are included, most annotations focus on the authors' observations and interpretations of structural relationships.

\subsection{Structural Characteristics Data Table}

Analyses of the seismic hazard from YFB faults (Geomatrix 1988, 1990, 1994, 1996; Zachariasen et al. 2006) have used some or all of the available references on the fold belt. Because of frequent disagreement between authors regarding YFB fold structural connectivity, a conclusion based on a literature search that is limited in scope risks being strongly biased. A comprehensive collection of available data and interpretations on individual structures in the YFB is therefore provided in Appendix C 
as an Excel-generated table, to facilitate comparison and contrast between the individual structures and to provide a quick reference for the relevant work associated with each structure.

Yakima Fold Belt structures incorporated into Appendix C include anticlines and associated minor faults, important anticlinal segments, major faults cutting YFB anticlines, and several synclines.

Structures without literature attention are not included in the table. Although lack of attention may be a result of inferred unimportance to seismic hazard, it is possible that some of these disregarded structures are potentially active. A brief summary of YFB structures and associated references detailed in Appendix $\mathrm{C}$ is displayed in Table 2.1.

All information included in Appendix C originates directly from the indicated literature sources. No interpretation of the cited data or opinions has been made.

Structural characteristics addressed in Appendix C include strike, dip, fault type, lateral length, segmentation, displacement, slip rate, evidence for and against Quaternary activity, age of latest activity, and relationship to other faults. Evidence for and against Quaternary activity is generally a presence or lack of geomorphic expression such as disrupted drainage, fault scarps, well-preserved lineaments, and displaced loess, flood, or ash deposits. Age of latest activity varies in calibration and error, but age dates often are provided in radiocarbon years before present $\left({ }^{14} \mathrm{C}\right.$ years $\left.\mathrm{BP}\right)$. Relationship to other faults includes such information as whether the structure cross cuts or is cross cut by other structures, whether relative location of two or more structures causes a change in strike, possible connection to an underlying décollement, intersection of two or more structures, and reference to influence by basement structures. Additionally, any other information deemed relevant to this topical report is included under a "Notes" column, which often addresses change in displacement over a lateral area. 
Table 2.1. Yakima Fold Belt Structures and Associated References (see Appendix C)

\begin{tabular}{|c|c|c|}
\hline Structure Name & Structure Type & References \\
\hline Ahtanum Ridge & Anticline and associated faults & Bentley et al. (1980) \\
\hline Columbia Hills & Anticline and associated faults & Piety et al. (1990) \\
\hline Horse Heaven Hills & Anticline and associated faults & $\begin{array}{l}\text { Anderson (1987); Bentley et al. (1980); } \\
\text { Geomatrix (1996); Piety et al. (1990); } \\
\text { Rigby and Othberg (1979); Sandness } \\
\text { et al. (1982) }\end{array}$ \\
\hline Reith anticline & Anticline & Piety (1990); Ferns et al. (in review) \\
\hline Saddle Mountains & Anticline and associated faults & Reidel (1984); West et al. (1996) \\
\hline Sedge Ridge & Anticline & Bentley et al. (1980) \\
\hline Service anticline & Anticline & $\begin{array}{l}\text { Piety et al. (1990); Ferns et al. (in } \\
\text { review) }\end{array}$ \\
\hline Smyrna anticline & Anticline & Reidel (1984) \\
\hline The Butte & Anticline & Farooqui and Thoms (1980) \\
\hline Toppenish Ridge & Anticline and associated faults & $\begin{array}{l}\text { Bentley et al. (1980); Campbell and } \\
\text { Bentley (1981); Piety et al. (1990) }\end{array}$ \\
\hline Ahtanum fault & Fault & Bentley et al. (1990) \\
\hline Arlington-Shutler Butte & Fault & Bentley et al. (1980); Piety et al. (1990) \\
\hline Badger Canyon fault & Fault/non-tectonic & Farooqui and Thoms (1980) \\
\hline Badger Mountain fault & Fault & Farooqui and Thoms (1980) \\
\hline Buroker fault & Fault & Farooqui and Thoms (1980) \\
\hline Finley Quarry & Fault & Farooqui and Thoms (1980) \\
\hline Frenchman Hills fault & Fault & Reidel (1984) \\
\hline Game Farm Hill & Fault/non-tectonic & Farooqui and Thoms (1980) \\
\hline Goldendale & Fault & Bentley et al. (1980) \\
\hline Kennewick-Cold Creek lineament & Fault/non-tectonic & Farooqui and Thoms (1980) \\
\hline Luna Butte & Fault & Bentley et al. (1980); Piety et al. (1990) \\
\hline Mill Creek & Fault & $\begin{array}{l}\text { Bentley et al. (1980); Campbell and } \\
\text { Bentley (1981); Campbell et al. (1995); } \\
\text { Geomatrix (1988); Geomatrix (1990); } \\
\text { Geomatrix (1996); Mullineaux et al. } \\
\text { (1977); Mullineaux et al. (1978); Piety } \\
\text { et al. (1990); Repasky and Campbell } \\
\text { (1998); Woodward-Clyde (1981); Yeats } \\
\text { (1986) }\end{array}$ \\
\hline Saddle Mountains fault & Fault & Reidel (1984); West et al. (1996) \\
\hline Silver Dollar & Fault & Farooqui and Thoms (1980) \\
\hline Wallula fault & Fault & $\begin{array}{l}\text { Gardener et al. (1981); Piety et al. } \\
\text { (1990); Ferns et al. (in review) }\end{array}$ \\
\hline Ahtanum syncline & Syncline & Bentley et al. (1980) \\
\hline Satus Basin & Syncline & Bentley et al. (1980) \\
\hline Toppenish syncline & Syncline & Bentley et al. (1980) \\
\hline
\end{tabular}





\subsection{Technical Positions}

There are several schools of thought regarding this technical issue. These schools of thought can generally be couched in terms of four different (alternative) conceptual models. One conceptual model suggests that all folds within the YFB are structurally and tectonically interconnected, behave the same, and should be assigned a common probability of activity. Conversely, another conceptual model suggests that although all the folds may be structurally and tectonically connected, they behave differently (particularly for short-term seismic predictions) and should be assigned individual probabilities of activity. A third conceptual model suggests that folds within the YFB are not structurally or tectonically connected and that each fold/structure should be considered unique and assigned individual probabilities of activity. Finally, a fourth conceptual model (or series of conceptual models) suggests that some groups of folds may be structurally and tectonically connected and that folds within those groups behave similarly and should be assigned a common probability of activity. The following sections explore these alternative conceptual models (ACMs) along with some examples of the supportive arguments. The reader is directed to Appendix $\mathrm{C}$ for a summary of key observations on each fold or fault structure.

\subsection{Alternative Conceptual Model 1}

\section{The Yakima Fold Belt is a kinematically consistent, structurally associated group of regionally coherent structures forming a single seismotectonic province.}

This ACM assumes that structures within the YFB are structurally and tectonically similar, differing more in the age of the most recent earthquake than in fundamental character. Thus, it may be more appropriate to model the fold belt as a single unit, with the constituent folds having identical behavior in terms of a single common probability of activity and/or coupling; that is if one fold is active, then all folds are active. Given the clear Quaternary activity (and resultant probability of activity of 1) of several structures widely distributed across the YFB, other less-studied folds would also be given a probability of activity of 1 . The following paragraphs present lines of evidence and relevant arguments from published literature that supports this ACM. Appendix C provides a more detailed comparison of structural features.

\subsubsection{Seismicity}

Piety et al. (1990, p. 46) noted that north-south compressive microseismicity found throughout the YFB is diffuse and unassociated with specific geologic structures. They further noted (p. A.3) that the major east- to northeast-trending anticlines are oriented perpendicular to this north-south compression and would be expected to result in growth of the anticlines and displacement along reverse/thrust faults. They further noted that intense folding reported in sediments of undetermined age overlying the Miocene basalt flows (Rigby and Othberg 1979) and a lack of Quaternary deposits of known age in relationship to the folds suggest that, although no direct evidence exists for late Quaternary uplift of these anticlines, uplift caused by subsurface fault rupture cannot be precluded (Piety et al. 1990, p. A.4). Thus, they assumed that anticlines in the southern YFB that lack evidence for surface faulting are inferred to have associated faults by analogy to anticlines further north, where exposures reveal thrust or reverse faults at the cores of the anticlines. The Piety et al. assumption thereby supports ACM 1 and the conservative approach taken by Zachariasen et al. (2006) that infers all main faults underlying the YFB folds be considered potential 
seismic sources (Piety et al. 1990, p. 2). Geomatrix (1996, Figures 3-8 and 3-9) also found that seismicity is not aligned along buried thrust or reverse faults. Such diffuse seismicity correlates with the small degree $(1 \mathrm{~mm} / \mathrm{yr})$ of shortening due to active contraction between Lind and Goldendale in the YFB (Miller et al. 2001, p. 173). Diffuse seismicity may indicate that no single anticlinal uplift is more likely to be a seismic source than any other structure in the YFB. In fact, seismicity in the YFB is concentrated in the surrounding synclines because these structures are more competent than the heavily deformed anticlines and cannot accommodate stress by a seismic movement (Reidel et al. 1994).

\subsubsection{Quaternary Surface Faulting}

Piety et al. (1990, p. 6) suggest that faults inferred to be associated with anticlines of the YFB yet lacking evidence for late Quaternary surface rupture could deform the ground surface and cause growth of the anticlines without rupturing the ground surface. Thus, evidence for Quaternary faulting on some structures and not on others does not refute ACM 1. In fact, Piety et al. further indicate that this type of deformation without surface rupture could result from earthquakes with a relatively high magnitude $(M=6.5)$. The potential for activity on folds that exhibit no recent displacement is justified by the likelihood that these folds are underlain by thrust faults similar to those under folds exhibiting surface rupture (Piety et al. 1990, p. 2). An earthquake below $M=7$ on such thrust faults would likely not result in surface rupture (Meghraoui et al. 1988, p. 197), which decreases the interpretative importance of lack of evidence of recent displacement. Piety et al. (1990, p. 47) state that faults located in the western United States with no surface rupture can have a maximum credible earthquake magnitude of around 6.0 6.5 .

Reidel et al. (1994) indicate that the pattern of Pleistocene-Holocene faulting is similar to that of the Pliocene and Miocene. The similarity in deformation from Miocene through Quaternary time suggests

“...that this Quaternary deformation is only the latest episode in a continuing history of regional compression..." (Campbell and Bentley 1981, p. 522). This implies that not only do similar stresses act throughout the region but also that lack of evidence of activity on a structure during any period does not predict behavior during other periods. Because "time periods" are not quantitatively defined, relatively recent data are considered more representative of the current period. Furthermore, because evidence for Quaternary displacement does exist for some YFB faults, and because compression is regional, YFB activity in the current period might be represented best by those structures exhibiting the most recent displacements. Mann and Meyer (1993, p. 863), based on their review of seismicity patterns and reconnaissance (e.g., aerial photography) mapping, support this by suggesting "Because...structures along the southeast extension of the OWL show evidence of youthful activity, it follows that large structures comprising the OWL of the Columbia Plateau may also be active." Geomatrix (1996, p. 3-12) also considered Quaternary displacements and deformation the best gauge for determining near-future activity in the YFB.

\subsubsection{Structural Similarity and Interrelationships}

Similar geometry and structure of folds within the YFB (e.g., Hagood 1986; Reidel et al. 1989, 1994) suggest similarity in the tectonic stress and response of these structures, suggesting contemporaneous (over a period of millions of years) development of the entire fold belt. Geomatrix (1996, p. 3-10) considers the fold geometry and structural data for the Umtanum anticline to be representative of the style and amount of compressive deformation in the YFB. Reidel (1984, p. 942) suggests that similarities of 
structures indicate they are exposed to the same tectonic stresses. He found that "studies of other folds in the province show a similar pattern of evolution suggesting that the age, timing, and growth rate of the Saddle Mountains provide a model for anticlinal folds of the Yakima Fold Belt." Additionally, the YFB is structurally and tectonically similar to other historically active fold belts, which likely indicates that the YFB itself could be active in the near future (Piety et al. 1990, p. 3).

The location and proximity of structures within the same fold belt also suggest similarity in behavior. Mann and Meyer (1993, p. 869) suggest that activity on one structure implies potential activity on another: They state that uncontroversial late Quaternary activity (Repasky and Campbell 1998; Campbell et al. 1995) on Toppenish Ridge implies that other YFB faults may be active (Whitney et al., unpublished data, $1986^{(\mathrm{a})}$ ). Furthermore, Mann and Meyer (1993, p. 869) maintain that the identical trends of the Rattlesnake-Wallula alignment (RAW) and the active Wallula fault zone (WFZ) make the likelihood of the RAW being inactive highly improbable. Evidence for Quaternary activity often is found on only one of several segments of a main fault or fault zone, such as the Satus Peak segment of the Mill Creek fault on Toppenish Ridge. Nevertheless, Mége and Reidel (2001) state that within individual faults, segments are strongly linked. This indicates that fault segments mechanically function as a unified fault (Mége and Reidel 2001, p. 3545). Meghraoui et al. (1988, p. 201) argued that on the El Asnam fault in Algeria, a fault structurally and tectonically similar to the main YFB faults, surface rupture occurred only during large earthquakes. Furthermore, movement occurred along the entire fault. This may suggest that YFB faults, such as the Mill Creek fault, that show Quaternary displacement along only a fraction of their length may, in fact, be capable of movement along their entire length.

\subsubsection{Décollement}

Similar YFB fold behavior (ACM 1) may be supported also by the presence of a décollement within the CRBG or underlying sedimentary rocks. Structural and mechanical analysis of the geometry of the Yakima folds is consistent with critical wavelength buckling of a strong elastic lid (basalts) over a relatively thick and incompetent substrate (basinal sedimentary rock) (Watters 1989, pp. 288-291). This indicates that the cause of movement is at least roughly similar for all YFB folds. Bruhn (1981, p. 10) also favors a fold belt model with a detachment or group of detachments within the CRBG, at a depth of approximately 3-5 km, suggesting that Quaternary deformation along the Mill Creek fault fits a model connecting the fault to a décollement and is similar to the other YFB folds displaying Miocene deformation.

\subsection{Alternative Conceptual Model 2}

The Yakima Fold Belt is a structurally associated group of regionally coherent structures, but, at least for short-term seismic predictions, individual folds have different seismogenic behavior.

(a) Whitney R, T Sawyer, A Ramelli, D Slemmons, H McKague, and D Chung. Structural Model, Deformation Style, and Age of Deformation of the Yakima Fold/Thrust Belt, South-Central Washington and North-Central Oregon; 1986 report submitted to and funded by the U.S. Nuclear Regulatory Commission, 163 pp. 
This ACM assumes that although structures within the YFB are structurally and tectonically similar, their recent activity (and therefore their near-term future activity) differs in age more than in fundamental character. Thus, it may be more appropriate to model the folds as having similar probability of coupling, segmentation, and fault displacement, but to model each of them as having a different probability of activity. Under this ACM, each YFB structure is assigned an independent probability of activity, emphasizing the importance of time scale when defining the activity of any structure. Arguments and published literature supporting this model are presented in the following paragraphs.

\subsubsection{Clustered Activity}

Zachariasen et al. (2006, p. 2-11) suggest "the sequence of events exposed in the Toppenish Ridge trenches requires recurrence intervals of a few thousand years for the last three events but 40-100 k.y. ${ }^{1}$ for the first three events." They attributed one possible reason for the difference in recurrence intervals, as a late Pleistocene-Holocene cluster of earthquakes at Toppenish Ridge. Reidel (1984) also found differences in deformation rates over time, with the period from 17 to about 10.5 Ma being a distinctly more active period of fold deformation than the period from 10.5 Ma to the present, with the rate of fold development during $17-10.5$ Ma accounting for approximately $80 \%$ of the total strain.

Beanland and Berryman (1989) have suggested that this type of clustered activity can occur in different fault sets and at different times, despite uniform tectonic stresses. Beanland and Berryman $(1989$, p. 459) indicate "....such episodic activity suggests that, although the whole region may respond evenly to the stresses, any individual fault may switch on and off." Further, they state "Sequential pulses of activity across a region, in response to a fairly uniformly applied stress, suggest that the structures within the region are interconnected" and "...that the individual faults are linked at depth into a regional crustal décollement zone within the basement." Beanland and Berryman (1989, p. 459) also indicate "The common basal sole thrust zone (mid-crustal décollement?) would provide a mechanism for transmitting stresses so that, for some time, one fault may be active, but later another fault may accommodate the deformation." However, others (Watters 1989, pp. 288-291; Bruhn 1981, p. 10) have suggested that the presence of a décollement might support similar rates and timing of deformation.

\subsubsection{Quaternary Surface Faulting}

As mentioned in the discussion of ACM 1 (Section 3.1.2), Campbell and Bentley (1981, p. 522) suggested that Quaternary deformation of YFB folds is an episode of activity within the long-term regional north-south compression. Although capable of supporting ACM 1, that idea may also apply to ACM 2. If structures experience episodes of activity, different structures may require stress relief at different times, resulting in active episodes that are out of phase throughout the fold belt. This correlates well with Zachariasen et al. (2006, p. 2-11), who suggested a change in recurrence rates for 40- to 100-kyr faults exposed in the Toppenish Ridge trenches compared to those that are only a few thousand years old. This also fits Beanland and Berryman's (1989) description of clustered activity experienced by faults connected through a décollement. Additionally, Meghraoui et al. (1988, p. 197) state "the long-term behavior of a fault zone may be examined as a succession of same size events, evenly or unevenly distributed over time." This behavior emphasizes the importance of time scale, which is the distinguishing difference between ACMs 1 and 2.

\footnotetext{
${ }^{1}$ Editor's note: It is assumed that Zachariasen et al. used "k.y." in place of "kyr" to indicate kiloyear(s).
} 


\subsection{Alternative Conceptual Model 3}

\section{Structures within the so-called Yakima Fold Belt represent different and separate structures more than related elements of a coherent structural domain.}

This ACM suggests that the seismogenic and behavioral characteristics of individual YFB structures differ significantly and thus the YFB does not behave as a coherent structural domain. Thus, it may be more appropriate to model individual folds differently in terms of probability of activity and/or coupling. Within this ACM, each YFB structure must therefore be assigned an independent probability of activity. The reader is directed to Appendix $\mathrm{C}$ for details regarding data and references pertinent to individual YFB structures. The following paragraphs present information supporting the structural independence of the YFB features. Appendix C provides a more detailed comparison of structural features.

\subsubsection{Seismicity}

Piety et al. (1990, p. 47) state that, although microseismicity in the Columbia Basin is generally diffuse and unassociated with geologic structures, the Milton-Freewater area in northeastern Oregon has experienced repeated seismic activity in historic times. They postulate that this may result from the intersection of the northeast-trending Blue Mountains anticline and northwest-trending RAW. However, information supporting a physical relationship between the two differently trending structures is not available. Like Piety et al. (1990), Geomatrix (1996) maintains that seismicity in the YFB is generally diffuse. Nevertheless, open clusters of seismic activity within the CRBG and basement can be identified in Figures 3-8 and 3-9 of Geomatrix (1996, pp. 3-66-3-67), respectively. The most prominent cluster is located north of the central Saddle Mountains in the CRBG (Geomatrix 1996, p. 3-10). Additional clusters are located south of the central Saddle Mountains and south of the western edge of the Umtanum Ridge-Gable Mountain anticline. Although clustering is not associated with underlying thrust or reverse faults (Geomatrix 1996, p. 3-10), Figure 3-8 shows that both Manastash Ridge and the Horse Heaven Hills have experienced low-magnitude, almost regularly spaced earthquakes in line with the ridges.

\subsubsection{Structural Characteristics and Interrelationships}

Geomatrix (1996, p. 3-10) suggested that the characteristics of the fault associated with any given fold are specific to that fold. Additionally, they maintain that the probability of activity of faults underlying YFB folds varies with individual folds. They assigned probability of activity to each anticline, based on its association with historical seismicity, evidence for late Quaternary fault displacements, geomorphic evidence for geologically recent deformation, association with neighboring structures showing evidence for Quaternary activity, pre-Quaternary history of deformation, and orientation relative to the present stress field (Geomatrix 1996, pp. 3-11-3-12). This manuscript treated probability of coupling similar to that of activity, individually evaluating each fold. The Geomatrix evaluation was based on evidence of Quaternary tectonic activity, the structural style, degree of deformation, paleoseismic slip evidence, association with neighboring folds, and location with respect to prominent basement structures (Geomatrix 1996, pp. 3-14-3-15). In determining fault characteristics, the document also assigned different crustal thicknesses and downdip widths to each fold, based on their modeled average crustal thickness of the basalts beneath the mapped fold (Geomatrix 1996, p. 3-20). 
Regarding specific YFB structures, an early report by Bruhn (1981, p. 5) emphasizes the potential differences in mechanical behavior between Umtanum Ridge and Gable Mountain, two structures that are frequently grouped (Lidke 2002). Bruhn claims that the exposed portion of the Gable Mountain fold is not a kink-band structure and notes that the structure shows little evidence for bedding parallel shear. Umtanum Ridge, on the other hand, is a kink-band structure, and bedding-parallel shear is quite evident in its development (Bruhn 1981, pp. 4-5). Campbell and Bentley (1981, p. 524) also single out a YFB structure, stating that "the Toppenish scarps have a unique position between two interpreted strike-slip faults, one with historic strike-slip movement." Because the Mill Creek fault on Toppenish Ridge is one of the few YFB structures with obvious late Quaternary displacement, this position may account for a possible difference in activity. If such positioning does greatly affect fault behavior, it may be that each fault should be evaluated independently based on proximity to and association with other structures. In the case of the Saddle Mountains, each of the Smyrna Bench, Eagle Lakes, and Saddle Gap segments may be influenced by reactivated faults in the basement (Reidel 1984, pp. 968-969), demonstrating that both vertical and horizontal associations between structures must be addressed.

\subsection{Alternative Conceptual Model 4}

\section{Structures within the Yakima Fold Belt can be divided into structurally and seismogenically similar groups.}

This ACM suggests that the structural and seismogenic characteristics differ greatly from one group of structures to another and may actually represent related elements of two or more cohesive structural domains. While each structure within a given group behaves similarly, behavior varies between groups. This variation is a result of the influence of two or more different seismogenic sources (e.g., some structures may be coupled while others are uncoupled). Thus, it may be more appropriate to attach a single, common probability of activity and a single common probability of coupling to each group of structures where the probability associated with one group is independent of the probability associated with another. Although a mix of coupled and uncoupled faults would constitute one possible subdivision for this ACM, there are numerous other possible combinations of structural groups. Some of these groups and associated supporting evidence and arguments are presented below. The reader is directed to Appendix $\mathrm{C}$ for details regarding possible connections between individual structures and different YFB or basement structures.

\subsubsection{Ridge Spacing and Orientation}

The regularly spaced anticlines in the YFB can be grouped into three domains on the basis of ridge spacing and orientations (Watters 1989). These groups consist of

- the northern domain, made up of the eastern segments of Umtanum Ridge, the Saddle Mountains, and the Frenchman Hills

- the central domain, composed of segments of Rattlesnake Ridge, the eastern segments of Horse Heaven Hills, Yakima Ridge, the western segments of Umtanum Ridge, Cleman Mountain, Bethel Ridge, and Manastash Ridge

- the southern domain, composed of Gordon Ridge, the Columbia Hills, the western segment of Horse Heaven Hills, Toppenish Ridge, and Ahtanum Ridge. 
Spacing and orientation are more variable in the central domain than in the remaining two domains, which Watters infers may be related to the central domain's inclusion of the CLEW (Watters 1989, p. 285). The differences in orientation may be a result of varying influence of tectonic stresses. Like Watters (1989), and perhaps because of that document, Geomatrix (1996, p. 3-14) evaluated three independent groups of folds and three separate folds for the purposes of assigning probabilities of coupling. Geomatrix (1996, p. 3-14) also notes the importance of relative location of prominent basement structures in determining fault characteristics.

\subsubsection{Pre-Basalt Bedrock Features and Coupling}

Tectonic stresses may vary within the Yakima fold belt because of bedrock features on the YFB margins and within the YFB itself. Basalt and pre-basalt bedrock (i.e., sediments and crystalline basement) within the interior of the fold belt may experience forces different from those experienced by bedrock on the northwest margin of the YFB; two exceptions are the Hog Ranch-Naneum cross-structure and White River-Naches River fault zone (Campbell 1989, p. 220). Specifically, basalt deformation decreases from the center of the YFB northwestward, with folds becoming more open and more gently dipping. Additionally, displacement along faults in pre-basalt rocks northwest of the CRBG margin often decreases toward the basalt margin to the south (Campbell 1989, p. 221). Basalts experience radially directed strain along the Columbia Basin margins because of steep slopes in these regions (Miner 2002), supporting potential differences in tectonic stresses within the YFB. These differences in deformation may indicate that further deformation and seismic activity is more likely to occur toward the center of the YFB as opposed to the margins of the belt. Campbell (1989) also raises the possibility that where basalt and pre-basalt structures are aligned, apparently relatively weak deformation may be accounted for by shear distribution, which would make deformation less visible. Where deeper and shallower structures are not aligned, Campbell maintains that a décollement may account for the gentle folds close to the YFB margin.

Mann and Meyer (1993) propose a progressive crustal detachment (décollement) within the basalts or pre-basalt sedimentary deposits that increases toward the northwest, as evidenced by the change from en echelon orientation of the three to four anticlines most proximal to Wallula Gap to different orientations in the remaining anticlines (Mann and Meyer 1993, p. 869). Similarly, Bruhn (1981, p. 10), although favoring a model that includes a décollement within the CRBG, introduces the possibility that there is a group of localized detachments or décollements. This situation would likely create groups of folds that could be modeled independently. If detachment does vary across the YFB, at least two groups of foldsthose underlain by faults linked by a detachment and those underlain by faults that do not - could be assigned independent probabilities of activity. A third group would be included in this assignment, should some non-décollement faults be judged as coupled to the basement.

Montgomery (2008) identified three types of dominant structures present beneath the Columbia Plateau, horst-like basement uplifts (e.g., the Hog Ranch-Naneum structure), a system of northwestsoutheast dextral, oblique-slip faults (e.g., the RAW), and a set of east-west folds commonly bounded by low-displacement thrust faults. He further indicates that the thrusted folds in the basalt have a complex, variable relationship to structures at depth; some thrust faults are detached from the basement, while others may be rooted in older basement faults. Thus, Montgomery (2008) suggests that indeed there may be some rationale for grouping YFB structures into seismogenically similar groups. 
Connection to the basement or influence of non-YFB structures on YFB folds and faults can be used to support both ACM 3 (Section 3.3.2) and ACM 4. Locations at which interaction with deep structures may result in additional stresses include the eastern edge of the Saddle Mountains Ridge as it dies out over the continental craton (Tolan et al. 2004) and the Frenchman Hills and Saddle Mountains-Manastash Ridge where they cross the Hog Ranch-Naneum Ridge anticline.

\subsubsection{Seismicity}

The YFB structures also could be divided into different groups with independent probabilities of activity based on clustered seismicity in the CRBG. As discussed in Section 3.3, seismicity clusters are present within the normally diffuse seismic activity of the YFB. Prominent clusters are located north of the Saddle Mountains and far to the north near Lake Chelan (Johnson 1989, p. 1325). Johnson further suggests that these clusters, which trend northwest, may be influenced by a continental rift buried under the basalts. Shallow earthquake clusters appear to be east-trending, and Johnson relates one such cluster to the Saddle Mountains anticline and fault. Alignment may be a result of possible lateral extension of the Chiwaukum graben and the Entiat fault along the eastern boundary of the graben (Johnson 1988, p. 1326). Grouping of seismicity may indicate that structures within each cluster should be treated as independent sets with independent probabilities of activity and that structures outside the clusters should be treated as one group during assignment of probability. If seismic clustering is important to determine grouping within ACM 4, note that seismicity tends to be concentrated in the synclines (Reidel et al. 1994). 


\subsection{Recommendations}

While the principal intent of this report is to provide information resources that could be used to inform seismic source characterization of the current state of uncertainty regarding the YFB as a structural entity, this section suggests areas of research and analysis that could, in the future, result in narrowing of these uncertainties.

Published documents frequently disagree regarding structural relationships and activity in the Columbia Basin. Although some areas of the YFB have been well studied for evidence of seismicity and geomorphic expression of faulting, there are not enough data on most YFB structures to definitively conclude whether activity on any given YFB folds indicates activity on all other structures. To decrease uncertainty on this issue, a variety of studies could be performed. The reader is directed to Zachariasen et al. (2006, pp. 3-2-3-4) for a more extensive description of prospective projects.

One of the most thorough methods of searching for geomorphic expression of Quaternary faultingparticularly scarps and landslides - is LiDAR, or light detection and ranging. LiDAR images of YFB topography would permit even tiny (sub-meter) scarps to be identified, which could lead to follow-up field trenching. This process would greatly reduce the bias toward relatively large displacements.

In addition to LiDAR, extensive field study of ALL folds in the YFB should be performed to better constrain the likelihood of recent deformation. Also, quantitative description of the influence of non-YFB structures (e.g., Hog Ranch-Naneum Ridge, continental craton) on individual YFB structures would be helpful in determining similarity in seismic sources throughout the YFB. 



\subsection{References Cited}

Anderson JL. 1987. The Structural Geology and Ages of Deformation of a Portion of the Southwest Columbia Plateau, Washington and Oregon. Ph.D. dissertation, University of Southern California, Los Angeles.

Beanland S and KR Berryman. 1989. Style and episodicity of late Quaternary activity on the PisaGrandview Fault Zone, Central Otago, New Zealand. New Zealand Journal of Geology and Geophysics 32:451-461.

Bentley RD, JL Anderson, NP Campbell, and DA Swanson. 1980. Stratigraphy and Structure of the Yakima Indian Reservation, with Emphasis on the Columbia River Basalt Group. Open-File Report 80200, U.S. Geological Survey, Reston, Virginia.

Bjornstad BN, K Winsor, and SD Unwin. 2012. A Summary of Fault Recurrence and Strain Rates in the Vicinity of the Hanford Site - Topical Report. PNNL-17497, Pacific Northwest National Laboratory, Richland, Washington.

Bruhn RL. 1981. Preliminary Analysis of Deformation in Part of the Yakima Fold Belt: South-Central Washington. Department of Geology and Geophysics, University of Utah, Salt Lake City.

Budnitz RJ, G Apostolakis, DM Boore, LS Cluff, KJ Coppersmith, CA Cornell, and PA Morris. 1997. Recommendations for Probabilistic Seismic Hazard Analysis: Guidance on Uncertainty and Use of Experts. NUREG/CR-6372, U.S. Nuclear Regulatory Commission, Washington, D.C.

Campbell NP. 1988. Structural Geology Along the Northwestern Columbia River Basalt Margin, Washington. Open File Report 88-5, Geology and Earth Resources Division, Washington State Department of Natural Resources, Olympia.

Campbell NP. 1989. Structural and stratigraphic interpretation of rocks under the Yakima fold belt, Columbia Basin, based on recent surface mapping and well data. In Volcanism and Tectonism in the Columbia River Flood-Basalt Province, SP Reidel and PR Hooper (eds), Special Paper 239, pp. 209-222. Geological Society of America, Boulder, Colorado.

Campbell NP and RD Bentley. 1981. Late Quaternary deformation of the Toppenish Ridge uplift in south-central Washington. Geology 9:519-524.

Campbell NP, T Ring, and T Repasky. 1995. Earthquake hazard study in the vicinity of Toppenish Basin, south-central Washington. In National Earthquake Hazards Reduction Program Annual Project Summaries: XXXVI - Volume I, ML Jacobson (comp), Open-File Report 95-210, pp. 291-306. U.S. Geological Survey, Menlo Park, California.

Chamness MA, K Winsor, and SD Unwin. 2012. A Summary of Coupled, Uncoupled, and Hybrid Tectonic Models for the Yakima Fold Belt - Topical Report. PNNL-17500, Pacific Northwest National Laboratory, Richland, Washington. 
DOE-ORP (U.S. Department of Energy Office of River Protection). 2002. U.S. Department of Energy Office of River Protection Position Concerning Assumed Probability of Tectonic Activity, and Adequacy of Ground Motion Attenuation Model Used in the Design of the Waste Treatment Plant. ORP/OSR-200222, Revision 0, U.S. Department of Energy Office of River Protection, Richland, Washington. Available at http://www.hanford.gov/orp/uploadfiles/2002-

22 DNFSB Seismic concerns resolution position paper_Rev_0.pdf (March 2008).

Farooqui SM and RC Thoms. 1980. Geologic Evaluation of Selected Faults and Lineaments, Pasco and Walla Walla Basins, Southeast Washington. Shannon \& Wilson, Inc., Richland, Washington.

Ferns ML, VS McConnell, and IP Madin. In review. Geology of the Umatilla River Basin, Umatilla County, Oregon. Oregon Department of Geology and Mineral Industries, Portland.

Gardner JN, MG Snow, and KR Fecht. 1981. Geology of the Wallula Gap Area, Washington. RHOBWI-LD-9, Rockwell Hanford Operations, Richland, Washington.

Geomatrix Consultants, Inc. 1988. Seismotectonic Evaluation of the Northern Cascade Mountains Geomorphic Province for Bumping Lake, Tieton, Keechelus, Kachess, Cle Elum, and Clear Creek Dams. Oakland, California.

Geomatrix Consultants, Inc. 1990. Seismotectonic Evaluation - Walla Walla Section of the Columbia Plateau Geomorphic Province. Oakland, California.

Geomatrix Consultants, Inc. 1994. Probabilistic Seismic Hazard Analysis - WNP-2 Nuclear Power Plant, Hanford, Washington. Oakland, California.

Geomatrix Consultants, Inc. 1996. Probabilistic Seismic Hazard Analysis, DOE Hanford Site, Washington. WHC-SD-W236A-TI-002, Rev. 1, Westinghouse Hanford Company, Richland, Washington.

Hagood MC. 1986. Structure and Evolution of the Horse Heaven Hills in South-Central Washington. Rockwell Hanford Operations, Richland, Washington.

Mann GM and CE Meyer. 1993. Late Cenozoic structure and correlations to seismicity along the Olympic-Wallowa Lineament, northwest United States. Geological Society of America Bulletin 105:853-871.

Mége D and SP Reidel. 2001. A method for estimating 2D wrinkle ridge strain from application of fault displacement scaling to the Yakima folds, Washington. Geophysical Research Letters 28(18):3545-3548.

Meghraoui M, R Jaegy, K Lammali, and F Albarede. 1988. Late Holocene earthquake sequences on the El Asnam (Algeria) thrust fault. Earth and Planetary Science Letters 90:187-203.

Miner AM. 2002. Seismicity and structure of the Columbia Basin: preliminary correlations. Abstracts with Programs, Geological Society of America, Boulder, Colorado. 
Montgomery SL. 2008. New exploration concepts highlight Columbia River basin's potential. Oil and Gas Journal 106(2):35-42.

Mullineaux DR, RE Wilcox, WF Ebaugh, R Fryxell, and M Rubin. 1977. Age of the last major scabland flood of eastern Washington, as inferred from associated ash beds of Mount St. Helens set S. Abstracts with Programs 9(7):1105, Geological Society of America, Boulder, Colorado.

Mullineaux DR, RE Wilson, WF Ebaugh, R Fryxell, and M Rubin. 1978. Age of the last major scabland flood of the Columbia Plateau in eastern Washington. Quaternary Research 10:171-180.

Myers CW and SM Price (eds). 1979. Geologic Studies of the Columbia Plateau, A Status Report. RHO-BWI-ST-4, Rockwell Hanford Operations, Richland, Washington.

Piety A, RC LaForge, and LL Foley. 1990. Seismic Sources and Maximum Credible Earthquakes for Cold Springs and McKay Dams, Umatilla Project, North-Central Oregon. Seismotectonic Report 90-1, U.S. Bureau of Reclamation, Denver, Colorado.

Raisz E. 1945. The Olympic-Wallowa lineament. American Journal of Science 243-a:479-485..

Reidel SP. 1984. The Saddle Mountains: the evolution of an anticline in the Yakima Fold Belt. American Journal of Science 284(8):942-978.

Reidel SP and TL Tolan. 1994. Late Cenozoic structure and correlation to seismicity along the OlympicWallowa Lineament, northwestern United States: Discussion. Geological Society of America Bulletin 106:1634-1648.

Reidel SP, KR Fecht, MC Hagood, and TL Tolan. 1989. The geologic evolution of the central Columbia Plateau.In Volcanism and Tectonism in the Columbia River Flood-Basalt Province, SP Reidel and PR Hooper (eds), Special Paper 239, pp. 247-264. Geological Society of America, Boulder, Colorado.

Reidel SP, NP Campbell, KR Fecht, and KA Lindsey. 1994. Late Cenozoic structure and stratigraphy of south-central Washington. In Regional Geology of Washington, ES Cheney and R Lasmanis (eds), Washington Division of Geology and Earth Resources Bulletin 80, pp. 159-180. Washington State Department of Natural Resources, Division of Geology and Earth Resources, Olympia.

Reiter L. 1990. Earthquake Hazard Analysis, Issues and Insights. Columbia University Press, New York.

Rigby JG and KL Othberg. 1979. Reconnaissance Surficial Geologic Mapping of the Late Cenozoic Sediments of the Columbia Basin, Washington. Open-File Report 79-3, Washington Department of Natural Resources, Division of Geology and Earth Resources, Olympia.

Sandness GA, CS Kimball, KE Schmeirer, and JW Lindberg. 1982. Report on Geologic Remote Sensing of the Columbia Plateau. PNL-3140, Pacific Northwest Laboratory, Richland, Washington.

Tabor RW, RB Waitt, VA Frizzell, Jr., DA Swanson, GR Byerly, and RD Bentley. 1982. Geologic map of the Wenatchee 1:100,000 quadrangle, central Washington. Miscellaneous Investigations Series Map I-1311, U.S. Geological Survey, Reston, Virginia. 
Tabor RW, VA Frizzell Jr., DB Booth, and RB Waitt. 2000. Geologic map of the Snoqualmie Pass $30 \mathrm{x}$ 60 minute quadrangle, Washington (scale 1:100,000). Geologic Investigations Series Map I-2538, U.S. Geological Survey, Reston, Virginia.

Tolan TL, NP Campbell, and KA Lindsey. 2004. 3D mapping of the Columbia River Basalt Group (CRBG) and the structural geology of the eastern Yakima fold belt (YFB) and the western Palouse slope: new structural features revealed and expanding the eastern limit of the YFB. Abstracts with Programs 36(4):34, Geological Society of America, Boulder, Colorado.

Watters TR. 1989. Periodically spaced anticlines of the Columbia Plateau. In Volcanism and Tectonism in the Columbia River Flood-Basalt Province, SP Reidel and PR Hooper (eds), Special Paper 239, pp. 283-292. Geological Society of America, Boulder, Colorado.

West MW, FX Ashland, AJ Busacca, GW Berger, and ME Shaffer. 1996. Late Quaternary deformation, Saddle Mountains anticline, south-central Washington. Geology 24(12):1123-1126.

Woodward-Clyde Consultants. 1981. Task D5, Toppenish Ridge Study. San Francisco, California.

Yeats RS. 1986. Active faults related to folding. Chapter 4 in Active Tectonics: Impact on Society, Geophysics Study Committee, Geophysics Research Forum, National Research Council, pp. 63-79. The National Academies Press, Washington, D.C.

Zachariasen J, S Olig, I Wong, and RS Yeats. 2006. Technical Review of the Seismic Source Model for the Yakima Fold Belt. URS Corporation, Oakland, California. 


\section{Appendix A}

Identification of Topical Reports to Be Prepared for the Future Hanford Site-Wide Probabilistic Seismic Hazard Analysis 



\title{
Appendix A
}

\section{Identification of Topical Reports to Be Prepared for the Future Hanford Site-Wide Probabilistic Seismic Hazard Analysis}

\author{
August 1, 2007
}

\section{A.1 Background}

A series of topical reports will be prepared as a resource to conducting a future probabilistic seismic hazard analysis (PSHA) of the Hanford Site. These topical reports will focus on technical issues that satisfy both following criteria:

1. It is an issue that is important to the seismic hazard. That is, the sensitivity of the calculated seismic hazard to the specific resolution of the issue is significant. Equivalently, uncertainty in the appropriate resolution of the issue results in a significant contribution to the total uncertainty in the estimate of the seismic hazard.

2. The correct resolution of the issue is a matter of contention in the expert community. That is, there are opposing schools of thought on the correct resolution, in contrast to a situation in which there is broad agreement that the correct resolution is uncertain.

The purpose of the topical reports is to summarize the range of opinions expressed by the expert community and to encapsulate the data and publications that support those opinions.

For a PSHA performed in conformance with Senior Seismic Hazard Analysis Committee (SSHAC) Study Level 2 or 3 (as in the case of the future Hanford Site PSHA), it is the function of the technical integrator (TI) to identify appropriate models and, in light of opinions expressed by the expert community, develop a probabilistic characterization of the aleatory variabilities and epistemic uncertainties associated with the models and their quantifications. The topical reports are not intended to resolve the technical issues they address but rather to provide clear expressions of the issues to the TIs, the TI teams, and the subject matter experts assembled to support the PSHA. Further, they provide a summary and compilation of all applicable data and information that pertain to the issues.

Here we identify the topical reports that will be developed as a resource to the future Hanford sitewide PSHA. The areas to be addressed in the topical reports were selected during a meeting on July 12 , 2007, involving the following participants:

- Tom Brouns, PNNL

- Ken Buxton, PNNL

- Kevin Coppersmith, Coppersmith Consulting

- Steve Reidel, Washington State University

- Alan Rohay, PNNL

- Steve Unwin, PNNL. 
The principal resource supporting the deliberations of this group was a report prepared by Kevin Coppersmith, Coppersmith Consulting, in which issues and data needs for a future PSHA were identified and evaluated (draft report of June 11, 2007). For convenience, the tabulation of issues from the Coppersmith report is included in this appendix as Table A.1. This table identifies technical issues related both to seismic source characterization (SSC) and to the analysis of ground motion attenuation (GMA).

\section{A.2 Conclusions}

With respect to the selection criteria identified previously, the following conclusions were drawn:

\section{A.2.1 Seismic Source Characterization}

Based on review of the SSC issues identified in Table A.1, the recommendation is to prepare topical reports addressing the following issues:

- SSC Issue 1: use of coupled versus uncoupled fault models - This issue is assessed to have a High level of contention with Moderate potential for impact on hazard estimation.

- SSC Issue 6: whether observation of activity along one Yakima fold structure should be considered an indicator of behavior along all Yakima fold structures - This topic is assessed to have a High level of contention with up to Moderate potential for impact on the hazard estimate.

- SSC Issue 7: whether slip rates should be greater than those used in the previous Hanford PSHA, which were based on post-Columbia River Basalt Group ages - This topic is assessed to be Moderately contentious with up to High potential for impact on the hazard estimation.

\section{A.2.2 Ground Motion Attenuation}

While the issue of using next generation attenuation (NGA) models could potentially have a high impact on the mean hazard and hazard uncertainty estimates, there is not a high level of contention associated with this or any of the GMA-related issues. Therefore, none of the topical reports will focus on GMA issues.

In addition to the three recommended topical reports identified above, an annotated bibliography of reports and data relevant to all SSC and GMA issues will be assembled, along with copies of all reports for use by the TIs, peer reviewers, and experts. 
Table A.1. Hanford Seismic Records and Scoping Analysis Issues and Data Needs (from Coppersmith Consulting, June 11, 2007)

\begin{tabular}{|c|c|c|c|c|}
\hline Issue $^{(\mathrm{a})}$ & Importance to Hazard $^{(\mathrm{b})}$ & $\begin{array}{c}\text { Level of } \\
\text { Contention }^{(\mathrm{c})}\end{array}$ & $\begin{array}{l}\text { Types of Data Needed to } \\
\text { Address for PSHA } \\
\text { (d) }\end{array}$ & Existing Data ${ }^{(\mathrm{e})}$ \\
\hline \multicolumn{5}{|c|}{ Seismic Source Characterization Issues } \\
\hline $\begin{array}{l}\text { 1. Greater weight should be } \\
\text { given to the coupled model } \\
\text { Uncoupled model means } \\
\text { smaller downdip extent, } \\
\text { smaller Mmax and source-site } \\
\text { distance } \\
\text { Coupling: preference for } \\
\text { uncoupled model is not } \\
\text { supported } \\
\text { Several lines of evidence } \\
\text { suggest that YFB structures } \\
\text { are related to basement } \\
\text { structures or could be traced to } \\
\text { basement structures } \\
\text { Lateral extent of Yakima fold } \\
\text { structures to east and to west } \\
\text { of CRB is uncertain }\end{array}$ & $\begin{array}{l}\text { Moderate: increased rupture } \\
\text { area for larger Mmax (lower } \\
\text { hazard) and larger moment } \\
\text { rate (higher hazard); } \\
\text { perhaps differences in } \\
\text { source to site distance }\end{array}$ & High & $\begin{array}{l}\text { - Deep geophysical data (reflection and } \\
\text { refraction) } \\
\text { - } \quad \text { High-resolution instrumental } \\
\text { seismicity (hypocenter distributions, } \\
\text { focal mechanisms } \\
\text { - Comparisons of locations of basement } \\
\text { and basalt structures } \\
\text { - Analysis of lateral extent of fold } \\
\text { - } \quad \text { Evidence for large single-event } \\
\text { displacements }\end{array}$ & $\begin{array}{l}\text { Rohay and Davis } 1983 \\
\text { Catchings and Mooney } 1988 \\
\text { Ludwin et al. } 1991 \\
\text { Tolan et al. 2004 } \\
\text { Garwood et al. } 2003 \\
\text { Reidel and Campbell } 1989 \\
\text { Campbell 1988, 1989 } \\
\text { Mann and Meyer } 1993 \\
\text { Lidke et al. 2003 } \\
\text { Reidel et al. 1989 } \\
\text { Beeson and Moran } 1979 \\
\text { Tolan } 1982 \\
\text { Tolan and Beeson } 1984 \\
\text { Tabor et al. 1982, } 1984 \\
\text { Tabor et al. 2000 } \\
\text { Reidel 1984 } \\
\text { Yeats et al. 1997 } \\
\text { Berberian 1981, } 1995 \\
\text { Ni and Barazangi } 1986 \\
\text { Lacombe et al. } 2006\end{array}$ \\
\hline $\begin{array}{l}\text { 2. Restructuring logic tree for } \\
\text { logical dependencies } \\
\text { - } \quad \text { Logic tree should be } \\
\text { restructured to have coupling } \\
\text { first } \\
\text { - } \quad \text { Treating basement sources } \\
\text { independently from coupling } \\
\text { can lead to "double counting" } \\
\text { (i.e., coupled faults extend and } \\
\text { co-exist with basement } \\
\text { structures) } \\
\text { Probability of activity comes } \\
\text { after segmentation } \\
\text { Fault activity should be } \\
\text { considered together with }\end{array}$ & $\begin{array}{l}\text { Low to moderate: If leads to } \\
\text { higher probability of } \\
\text { activity, hazard will increase } \\
\text { for nearby folds }\end{array}$ & $\begin{array}{l}\text { Moderate to } \\
\text { High }\end{array}$ & $\begin{array}{l}\text { - Analysis; no new data (see data needs } \\
\text { for probability of activity below) }\end{array}$ & \\
\hline
\end{tabular}




\begin{tabular}{|c|c|c|c|c|}
\hline Issue $^{(a)}$ & Importance to Hazard $^{(b)}$ & $\begin{array}{c}\text { Level of } \\
\text { Contention }^{(\mathrm{c})}\end{array}$ & $\begin{array}{l}\text { Types of Data Needed to } \\
\text { Address for PSHA }^{(\mathrm{d})}\end{array}$ & Existing Data ${ }^{(\mathrm{e})}$ \\
\hline \multicolumn{5}{|c|}{ Seismic Source Characterization Issues } \\
\hline $\begin{array}{l}\text { coupling, since faults rooted in } \\
\text { the basement are more likely } \\
\text { to be active }\end{array}$ & & & & \\
\hline $\begin{array}{l}\text { 3. Evidence of activity on YFB } \\
\text { structures may be difficult to } \\
\text { recognize } \\
\text { Large Quaternary fault } \\
\text { ruptures could be present on } \\
\text { many Yakima folds, but could } \\
\text { be broadly distributed, blind } \\
\text { faulting, or obscured in the } \\
\text { Quaternary record due to low } \\
\text { rates } \\
\text { Absence of surface expression } \\
\text { of primary slip does not } \\
\text { preclude activity on } \\
\text { subsurface fault }\end{array}$ & $\begin{array}{l}\text { Low to moderate: If leads to } \\
\text { higher probability of } \\
\text { activity, hazard will increase } \\
\text { for nearby folds }\end{array}$ & $\begin{array}{l}\text { Moderate to } \\
\text { High }\end{array}$ & $\begin{array}{l}\text { Detailed maps of Quaternary deposits } \\
\text { (including Touchet beds) and their } \\
\text { distribution relative to folds for signs } \\
\text { of uplift or deformation } \\
\text { - } \quad \text { Geomorphic analysis of Quaternary } \\
\text { surfaces for evidence of distributed } \\
\text { faulting, tilting } \\
\text { - Analysis of high resolution } \\
\text { instrumental seismicity and focal } \\
\text { mechanisms for 3-d distribution of } \\
\text { fault planes and potential for blind } \\
\text { faulting }\end{array}$ & $\begin{array}{l}\text { Yeats } 1986 \\
\text { Yeats et al. } 1997 \\
\text { Lidke et al. } 2003 \\
\text { Bentley et al. } 1980 \\
\text { Campbell and Bentley } 1981 \\
\text { Campbell et al. } 1995 \\
\text { Repasky and Campbell } 1998 \\
\text { West and Shaffer } 1988 \\
\text { West et al. } 1996 \\
\text { West } 1998 \\
\text { S. Personius } 2006 \\
\text { Rigby and Othberg } 1979 \\
\text { Piety et al. } 1990 \\
\text { Sandness et al. 1982 } \\
\text { Finnegan and Montgomery } \\
2003\end{array}$ \\
\hline $\begin{array}{l}\text { 4. Instrumental seismicity data } \\
\text { are not reliable indicators of } \\
\text { future activity } \\
\text { - Instrumental seismicity is not } \\
\text { long enough to illuminate fault } \\
\text { planes }\end{array}$ & $\begin{array}{l}\text { Low to moderate: one of } \\
\text { several criteria for assessing } \\
\text { the activity of folds; } \\
\text { hypocentral distribution } \\
\text { sheds light on seismogenic } \\
\text { behavior of basalts, } \\
\text { sediments, basement }\end{array}$ & Moderate & $\begin{array}{l}\text { - Comprehensive catalog of all } \\
\text { historical and instrumental events } \\
\text { - Focal mechanisms and depth } \\
\text { distributions for well-resolved events }\end{array}$ & $\begin{array}{l}\text { Reidel et al. } 1994 \\
\text { Rohay and Davis } 1983 \\
\text { Rohay } 2003 \\
\text { Ludwin et al. } 1991 \\
\text { Miner 2002a, b } \\
\text { Finnegan and Montgomery } \\
2003 \\
\text { Crider et al. } 2003 \\
\text { Bakun et al. } 2002\end{array}$ \\
\hline $\begin{array}{l}\text { 5. Large historical earthquakes } \\
\text { and paleoseismologic } \\
\text { evidence have not been } \\
\text { considered } \\
\text { 1872 Lake Chelan EQ M } 6.8 \\
\text { and ongoing seismicity zone } \\
\text { consistent with blind thrust } \\
\text { faulting and looks like YFB }\end{array}$ & $\begin{array}{l}\text { Low to Moderate: Some } \\
\text { effect on Mmax; possibly } \\
\text { recurrence; not source- } \\
\text { specific (this is data related } \\
\text { to prehistorical shaking } \\
\text { effects) }\end{array}$ & $\begin{array}{l}\text { Moderate to } \\
\text { High (USGS } \\
\text { has focused } \\
\text { on } 1872 \\
\text { earthquake) }\end{array}$ & $\begin{array}{l}\text { - Studies of intensity distributions for } \\
\text { historical earthquakes } \\
\text { - } \quad \text { Field studies of locations of } \\
\text { prehistorical shaking effects } \\
\text { (paleoliquefaction, disturbed lake } \\
\text { sediments) } \\
\text { - Maps of intensity and paleo-intensity } \\
\text { to assess possible causative source(s) }\end{array}$ & $\begin{array}{l}\text { Fecht et al. } 1999 \\
\text { I. Madin pers. comm. } 2006 \\
\text { Bakun et al. } 2002 \\
\text { Crider et al. } 2003\end{array}$ \\
\hline
\end{tabular}




\begin{tabular}{|c|c|c|c|c|}
\hline Issue $^{(a)}$ & Importance to Hazard $^{(b)}$ & $\begin{array}{c}\text { Level of } \\
\text { Contention }^{(c)}\end{array}$ & $\begin{array}{l}\text { Types of Data Needed to } \\
\text { Address for PSHA }{ }^{(\mathrm{d})}\end{array}$ & Existing Data $^{(\mathrm{e})}$ \\
\hline \multicolumn{5}{|c|}{ Seismic Source Characterization Issues } \\
\hline $\begin{array}{l}\text { - Clastic dikes and sills could be } \\
\text { liquefaction features from } \\
\text { shaking } \\
\text { - Touchet beds could be used } \\
\text { for assessing fold deformation }\end{array}$ & & & & \\
\hline $\begin{array}{l}\text { 6. Observations of activity } \\
\text { along one fold structure } \\
\text { should be indicator of } \\
\text { behavior along all fold } \\
\text { structures } \\
\text { Mapped normal faults that } \\
\text { suggest deeper faulting on } \\
\text { Toppenish and Horse Heaven } \\
\text { could be present on other } \\
\text { faults as well; No clear basis } \\
\text { for concluding that these folds } \\
\text { are different that all other } \\
\text { Yakima folds } \\
\text { Evidence for Quaternary } \\
\text { deformation distributed } \\
\text { throughout the fold belt means } \\
\text { that most and perhaps all of } \\
\text { the fold structures are likely } \\
\text { active } \\
\text { o Evidence at Toppenish } \\
\text { Ridge, Saddle Mtn and } \\
\text { Ahtanum means is } \\
\text { representative of the } \\
\text { entire fold belt } \\
\text { o Geomorphic evidence of } \\
\text { Quaternary deformation } \\
\text { at Yakima Ridge, } \\
\text { Umtanum Ridge, and } \\
\text { HHH }\end{array}$ & $\begin{array}{l}\text { Low to moderate: If leads to } \\
\text { higher probability of } \\
\text { activity, hazard will increase } \\
\text { for nearby folds }\end{array}$ & High & $\begin{array}{l}\text { - Structural and tectonic models of } \\
\text { YFB, including kinematics and timing } \\
\text { of deformation throughout the } \\
\text { province } \\
\text { - Comparison of YFB to appropriate } \\
\text { analogues to assess potential for } \\
\text { differences in activity among } \\
\text { structures } \\
\text { - } \\
\text { activity will be applicable to this } \\
\text { assessment] }\end{array}$ & $\begin{array}{l}\text { Bentley et al. } 1980 \\
\text { Campbell and Bentley } 1981 \\
\text { Campbell et al. 1995 } \\
\text { Repasky and Campbell } 1998 \\
\text { West and Shaffer 1988 } \\
\text { West et al. 1994,1996 } \\
\text { West 1997 } \\
\text { S. Personius written comm. } \\
\text { 2006 } \\
\text { WPPSS 1982 } \\
\text { Reidel et al. 1994 } \\
\text { Grolier and Bingham 1971 } \\
\text { West and Shaffer 1988 } \\
\text { Shaffer and West 1989 } \\
\text { Farooqui and Thoms 1980 } \\
\text { Kienle et al. 1979 } \\
\text { Reidel et al. 1994 } \\
\text { McQuarrie 1993 } \\
\text { Piety et al. 1990 } \\
\text { Foundation Sciences 1980 } \\
\text { Anderson and Tolan 1986 } \\
\text { Reidel et al. 1994 } \\
\text { Lidke et al. 2003 } \\
\text { Lidke 2002a-d, 2003a-e } \\
\text { Lidke and Bucknam 2002,2003 } \\
\text { Personius and Lidke 2003a-d } \\
\text { Beanland and Berryman 1989 } \\
\text { Yeats 1986 } \\
\text { Reidel 1984 } \\
\text { Reidel and Campbell 1989 } \\
\text { Finnegan and Montgomery } \\
\text { 2003 } \\
\text { WPPS 1982 }\end{array}$ \\
\hline
\end{tabular}




\begin{tabular}{|c|c|c|c|c|}
\hline Issue $^{(a)}$ & Importance to Hazard $^{(\mathrm{b})}$ & $\begin{array}{c}\text { Level of } \\
\text { Contention }^{(c)}\end{array}$ & $\begin{array}{l}\text { Types of Data Needed to } \\
\text { Address for PSHA }\end{array}$ & Existing Data $^{(\mathrm{e})}$ \\
\hline \multicolumn{5}{|c|}{ Seismic Source Characterization Issues } \\
\hline $\begin{array}{l}\text { YFB is single structural entity, } \\
\text { so folds scattered throughout } \\
\text { the fold belt are active and the } \\
\text { rest are therefore active }\end{array}$ & & & & $\begin{array}{l}\text { Reidel and Fecht } 1994 \\
\text { Schuster et al.1997 } \\
\text { Rigby and Othberg } 1979 \\
\text { Sandness et al. } 1982 \\
\text { Hemphill-Haley } 1999 \\
\text { Mann and Meyer } 1993 \\
\text { Wong et al. } 2002 \\
\text { Kuehn 1995 } \\
\text { Glass } 1977 \\
\text { Walsh et al. } 1997\end{array}$ \\
\hline $\begin{array}{l}\text { 7. Recurrence rates may be } \\
\text { higher than estimated using } \\
\text { post-CRB ages } \\
\text { - Geodetic rates of N-S } \\
\text { contraction could be as high as } \\
2 \mathrm{~mm} / \mathrm{yr} \\
\text { o Could use geodetic data } \\
\text { to characterize } \\
\text { deformation rates of } \\
\text { crustal seismic sources } \\
\text { - Not enough uncertainty in slip } \\
\text { rate: geodetic and rates from } \\
\text { those folds well-studied } \\
\text { (Toppenish and Ahtanum) } \\
\text { could be used for the other } \\
\text { folds as well }\end{array}$ & $\begin{array}{l}\text { Moderate to High: hazard } \\
\text { results vary linearly with } \\
\text { recurrence rate }\end{array}$ & $\begin{array}{l}\text { Low to } \\
\text { Moderate }\end{array}$ & $\begin{array}{l}\text { - Fold/fault-specific Quaternary slip rate } \\
\text { estimates, based on observed } \\
\text { displacements } \\
\text { - Slip rate estimates based on } \\
\text { deformation (uplift, tilt, folding) of } \\
\text { Quaternary deposits and/or } \\
\text { geomorphic analysis } \\
\text { - Fold/fault-specific paleoseismic data } \\
\text { on recurrence intervals for surface } \\
\text { rupturing or surface deforming events } \\
\text { - } \quad \text { High-resolution geodetic data } \\
\text { Information [see issue above] } \\
\text { suggesting that recurrence rate } \\
\text { information on single structure in } \\
\text { province can be used for other } \\
\text { structures in province }\end{array}$ & $\begin{array}{l}\text { West et al. } 1996 \\
\text { West } 1997 \\
\text { Prescott and Savage } 1984 \\
\text { Savage et al. } 1981 \\
\text { Miller et al. } 2001 \\
\text { Miller and Johnson } 2002 \\
\text { Ning and Qamar } 2003 \\
\text { McCaffrey } 2002 \\
\text { McCaffrey written comm. } 2006 \\
\text { T. Melbourne 2006 } \\
\text { W. Thatcher written comm. } \\
\text { 2006 } \\
\text { Reidel et al. } 1994 \\
\text { Reidel 1984 } \\
\text { Reidel et al. } 1989 \\
\text { Bentley et al. 1980 } \\
\text { Campbell and Bentley } 1981 \\
\text { Campbell et al. 1995 } \\
\text { Repasky and Campbell } 1998\end{array}$ \\
\hline $\begin{array}{l}\text { 8. Nature of the basement } \\
\text { rocks } \\
\text { - Assumed basement rocks are } \\
\text { crystalline, but may be } \\
\text { Mesozoic continental-margin } \\
\text { rocks } \\
\text { O Reference made to core in } \\
\quad \text { Darcell oil-exploratory }\end{array}$ & $\begin{array}{l}\text { Low: could affect } \\
\text { assessments of maximum } \\
\text { seismogenic depth, } \\
\text { dimensions of structures in } \\
\text { basement }\end{array}$ & Low & $\begin{array}{l}\text { Deep drilling data and/or deep } \\
\text { geophysics } \\
\text { Geologic interpretations of } \\
\text { comparable rocks in adjacent domains } \\
\text { to east and west }\end{array}$ & $\begin{array}{l}\text { Catchings and Mooney } 1988 \\
\text { S.P. Reidel, pers. comm. to } \\
\text { R. Yeats } 2006\end{array}$ \\
\hline
\end{tabular}




\begin{tabular}{||l|c|c|c|c||}
\hline \multicolumn{1}{||l||}{ Issue $^{(\mathrm{a})}$} & \multicolumn{1}{|c||}{$\begin{array}{c}\text { Level of } \\
\text { Contention }^{(\mathrm{c})}\end{array}$} & $\begin{array}{c}\text { Types of Data Needed to } \\
\text { Address for PSHA }^{(\mathrm{d})}\end{array}$ & Existing Data $^{(\mathrm{e})}$ \\
\hline \multicolumn{7}{|c||}{ Seismic Source Characterization Issues } & \\
\hline $\begin{array}{l}\text { well (S.P. Reidel pers. } \\
\text { Comm. 2006) }\end{array}$ & & & \\
\hline \hline
\end{tabular}

\begin{tabular}{|c|c|c|c|c|}
\hline Issue $^{(a)}$ & Importance to Hazard $^{(b)}$ & $\begin{array}{c}\text { Level of } \\
\text { Contention }\end{array}$ & $\begin{array}{l}\text { Types of Data Needed to } \\
\text { Address for PSHA }\end{array}$ & Existing Data $^{(\mathrm{e})}$ \\
\hline \multicolumn{5}{|c|}{ Ground Motion Attenuation Issues } \\
\hline $\begin{array}{ll}\text { 9. } & \text { Many existing applicable } \\
\text { ground motion models will } \\
\text { be superceded by PEER } \\
\text { Next Generation Attenuation } \\
\text { models } \\
\text { The NGA models should be } \\
\text { available in time for this } \\
\text { PSHA; the PEER reports will } \\
\text { be completed and a special } \\
\text { issue of Spectra is being } \\
\text { developed (final papers due } \\
\text { July?) }\end{array}$ & $\begin{array}{l}\text { Moderate to High: GM } \\
\text { attenuation is typically } \\
\text { largest contributor to mean } \\
\text { hazard and to total hazard } \\
\text { uncertainty }\end{array}$ & Moderate & $\begin{array}{l}\text { - Will need final suite of NGA } \\
\text { models }^{(\mathrm{f})} \text {, including discussions of } \\
\text { applicability for non-California site } \\
\text { conditions }\end{array}$ & $\begin{array}{l}\text { Boore and Atkinson } 2006 \\
\text { Campbell and Bozorgnia } 2006 \\
\text { Chiou and Youngs } 2006 \\
\text { Idriss } 2007\end{array}$ \\
\hline $\begin{array}{l}\text { 10. The NGA models will be } \\
\text { applicable to CA conditions } \\
\text { and each model will require } \\
\text { transfer function for } \\
\text { application to Hanford } \\
\text { - To use the NGA attenuation } \\
\text { models, a transfer function } \\
\text { from CA conditions to generic } \\
\text { site conditions will need to be } \\
\text { developed }\end{array}$ & Moderate & $\begin{array}{l}\text { Low to } \\
\text { Moderate }\end{array}$ & $\begin{array}{l}\text { - Bob Youngs developing this now for } \\
\text { the existing models, but not NGA, for } \\
\text { the WTP at the surface } \\
\text { Consideration of revisions, if any, } \\
\text { needed from Youngs' work for Vs } 30 \\
\text { or other locations in site profile }\end{array}$ & \\
\hline $\begin{array}{l}\text { 11. The suite of NGA models } \\
\text { will not define the full } \\
\text { epistemic uncertainty, more } \\
\text { will be needed } \\
\text { - The USGS will also be } \\
\end{array}$ & Moderate & Moderate & $\begin{array}{l}\text { - Consideration of other alternative GM } \\
\text { models to span the range of aleatory } \\
\text { variability } \\
\text { - Comparison with epistemic } \\
\text { uncertainties for PSHAs in other }\end{array}$ & \\
\hline
\end{tabular}




\begin{tabular}{|c|c|c|c|c|c|}
\hline & Issue $^{(a)}$ & Importance to Hazard $^{(\mathfrak{b})}$ & $\begin{array}{c}\text { Level of } \\
\text { Contention }^{(c)}\end{array}$ & $\begin{array}{l}\text { Types of Data Needed to } \\
\text { Address for PSHA }\end{array}$ & Existing Data ${ }^{(\mathrm{e})}$ \\
\hline \multicolumn{6}{|c|}{ Ground Motion Attenuation Issues } \\
\hline & $\begin{array}{l}\text { looking at how to use the } \\
\text { NGA models and will } \\
\text { probably define some arbitrary } \\
\text { factor to represent epistemic } \\
\text { uncertainty; this can be } \\
\text { considered in developing the } \\
\text { site model }\end{array}$ & & & $\begin{array}{ll} & \text { studies } \\
\text { - } & \text { Consider USGS results }\end{array}$ & \\
\hline - & $\begin{array}{l}\text { Representative site } \\
\text { conditions will need to be } \\
\text { developed for site-wide } \\
\text { application } \\
\text { Develop a reference site } \\
\text { profile (or profiles) that is } \\
\text { representative of the locations } \\
\text { at Hanford where the hazard } \\
\text { assessment will be needed, } \\
\text { including the appropriate } \\
\text { epistemic uncertainty model } \\
\text { (representative site profiles) }\end{array}$ & Moderate & $\begin{array}{l}\text { Low to } \\
\text { Moderate }\end{array}$ & $\begin{array}{l}\text { - Identify locations where PSHA may } \\
\text { be applied in the future } \\
\text { - Compile data regarding shear wave } \\
\text { velocity structure in upper few } \\
\text { hundred meters } \\
\text { - In absence of site-specific data, use } \\
\text { geologic models to interpret velocity } \\
\text { structure }\end{array}$ & \\
\hline & $\begin{array}{l}\text { Decision needs to be made } \\
\text { regarding the proper } \\
\text { interface between PSHA } \\
\text { ground motions and } \\
\text { subsequent site response } \\
\text { analysis } \\
\text { Decisions need to be made } \\
\text { regarding the interface } \\
\text { (surface, Vs 30, or otherwise) } \\
\text { between the PSHA ground } \\
\text { motion models and the site } \\
\text { response models that might be } \\
\text { developed at specific sites }\end{array}$ & Low to Moderate & Low & $\begin{array}{l}\text { Consideration of NUREG-6728 } \\
\text { approaches and DNFSB desires } \\
\text { regarding need for location of input } \\
\text { spectra prior to site response analysis }\end{array}$ & \\
\hline & $\begin{array}{l}\text { Some ground motion models } \\
\text { may require range of } \\
\text { assessments for application }\end{array}$ & Low to Moderate & Low & $\begin{array}{ll}\text { - } & \text { Most data will come from seismic } \\
\text { source characterization model } \\
\text { - } & \text { Studies of kappa, such as }\end{array}$ & \\
\hline
\end{tabular}




\begin{tabular}{|c|c|c|c|c|c|}
\hline & Issue $^{(a)}$ & Importance to Hazard $^{(\mathrm{b})}$ & $\begin{array}{c}\text { Level of } \\
\text { Contention }\end{array}$ & $\begin{array}{l}\text { Types of Data Needed to } \\
\text { Address for PSHA }\end{array}$ & Existing Data $^{(\mathrm{e})}$ \\
\hline \multicolumn{6}{|c|}{ Ground Motion Attenuation Issues } \\
\hline & $\begin{array}{l}\text { (crustal vs. subduction, style } \\
\text { of faulting, distance } \\
\text { measure, kappa) }\end{array}$ & & & $\begin{array}{l}\text { microseismicity analysis, analogues } \\
\text { based on geologic models }\end{array}$ & \\
\hline $\begin{array}{l}\text { (a) } \\
\text { (b) } \\
\text { (c) } \\
\text { (d) } \\
\text { (e) } \\
\text { (f) }\end{array}$ & $\begin{array}{l}\text { Seismic source characterization } \\
\text { discussions with ground motion } \\
\text { Detailed sensitivity studies of th } \\
\text { other PSHA studies. } \\
\text { Judgment based on review of ex } \\
\text { Data are identified that are typic } \\
\text { This column identifies existing } \\
\text { assigned to the various issues. } \\
\text { NGA references given are the c } \\
\text { posted are subject to revision ar } \\
\text { January 19, 2007) for review an } \\
\text { subject to further evaluation by } \\
\text { responsibility of the user. Incor } \\
\text { Spectra will be publishing a spe } \\
\text { 2008. }\end{array}$ & $\begin{array}{l}\text { sues identified primarily bas } \\
\text { xperts. } \\
\text { effect of each issue on hazar } \\
\text { ting documents. } \\
\text { ly needed to address the tecl } \\
\text { ta that address the issue. Fo } \\
\text { ent set as provided on the P } \\
\text { enhancement. As stated on } \\
\text { trial use. Additional reports } \\
\text { e authors and changes may } \\
\text { ration of directivity effects } \\
\text { al issue on results obtained }\end{array}$ & $\begin{array}{l}\text { on Zachariasen } \\
\text { aave not been co } \\
\text { cal issue; identi } \\
\text { eismic source ch } \\
\text { R website. Hov } \\
\text { website; "Upd } \\
11 \text { be added to th } \\
\text { made as a result } \\
\text { the models is un } \\
m \text { the Next Gen }\end{array}$ & $\begin{array}{l}\text { (2006); ground motion attenuation is } \\
\text { ted. The assessment shown is based } \\
\text { on of data here does not necessarily in } \\
\text { terization, the references/data cited in } \\
\text { they are incomplete (two more mode } \\
\text { beports of NGA models are provided o } \\
\text { site as they are completed. The NG } \\
\text { is process. Use of the NGA models fo } \\
\text { levelopment and not yet implemented. } \\
\text { on Attenuation (NGA) project. The ex }\end{array}$ & $\begin{array}{l}\text { d on experience and } \\
\text { nt and experience on } \\
\text { uch data currently exist. } \\
\text { en et al. (2006) are } \\
\text { ng developed) and those } \\
\text { R web site (posted on } \\
\text { motion models are } \\
\text { oose is the sole } \\
\text { Irnal Earthquake } \\
\text { blication date is March }\end{array}$ \\
\hline
\end{tabular}




\section{A.3 Sources Cited in Table A.1}

Anderson JL and TL Tolan. 1986. Ages of wrench faulting in interridge basins, southwest Columbia Plateau, Washington and Oregon. Abstracts with Programs 18:82, Geological Society of America, Boulder, Colorado.

Bakun WH, RA Haugerud, MG Hopper, and RS Ludwin. 2002. The December 1872 Washington State earthquake. Bulletin of the Seismological Society of America 92:3239-3258.

Beanland S and KR Berryman. 1989. Style and episodicity of late Quaternary activity on the PisaGrandview Fault Zone, Central Otago, New Zealand. New Zealand Journal of Geology and Geophysics $32: 451-461$.

Beeson MH and MR Moran. 1979. Columbia River Basalt Group stratigraphy in western Oregon. Oregon Geology 41:11-14.

Bentley RD, JL Anderson, NP Campbell, and DA Swanson. 1980. Stratigraphy and Structure of the Yakima Indian Reservation, with Emphasis on the Columbia River Basalt Group. Open-File Report 80200, U.S. Geological Survey, Reston, Virginia.

Bentley RD, NP Campbell, and JE Powell. 1993. Geologic Maps of Part of the Yakima Fold Belt, Northeastern Yakima County, Washington. Open File Report 93-3, Washington State Department of Natural Resources, Division of Geology and Earth Resources, Olympia.

Bentley RD and NP Campbell. 1983. Geologic map of the Yakima quadrangle, Washington (1 sheet, scale 1:62,500). Map GM-29, Washington State Department of Natural Resources, Division of Geology and Earth Resources, Olympia.

Berberian M. 1981. Active faulting and tectonics of Iran. In Zagros-Hindu-Kush-Himalaya Geodynamic Evolution, HK Gupta and FM Delany (eds), Geodynamic Series 3, pp. 33-69. American Geophysics Union, Washington, D.C.

Berberian M. 1995. Master "blind" thrust faults hidden under the Zagros folds: Active basement tectonics and surface morphotectonics. Tectonophysics 241:193-224.

Boore DM and GM Atkinson. 2006. Boore-Atkinson Provisional NGA Empirical Ground-Motion Model for the Average Horizontal Component of PGA, PGV and SA at Spectral Periods of 0.05, 0.1,0.2, 0.3, 0.5, 1, 2, 3, 4, and 5 seconds. PEER-Lifelines Next Generation Project (Revised 27 October 2006), Pacific Earthquake Engineering Research Center, University of California, Berkeley.

Campbell KW and Y Bozorgnia. 2006. Campbell-Bozorgnia NGA Empirical Ground Motion Model for the Average Horizontal Component of PGA, PGV, PGD and SA at Selected Spectral Periods Ranging from 0.01-10.0 Seconds (Version 1.1). Pacific Earthquake Engineering Research Center, University of California, Berkeley.

Campbell NP. 1983. Correlation of late Cenozoic gravel deposits along the Yakima River drainage from Ellensburg to Richland, Washington. Northwest Science 57:179-193. 
Campbell NP. 1988. Structural Geology Along the Northwestern Columbia River Basalt Margin, Washington. Open File Report 88-5, Washington State Department of Natural Resources, Geology and Earth Resources Division, Olympia.

Campbell NP. 1989. Structural and stratigraphic interpretation of rocks under the Yakima fold belt, Columbia Basin, based on recent surface mapping and well data. In Volcanism and Tectonism in the Columbia River Flood-Basalt Province, SP Reidel and PR Hooper (eds). Special Paper 239, Geological Society of America, Boulder, Colorado.

Campbell NP and RD Bentley. 1981. Late Quaternary deformation of the Toppenish Ridge uplift in south-central Washington. Geology 9:519-524.

Campbell NP, T Ring, and T Repasky. 1995. Earthquake Hazard Study of the Vicinity of Toppenish Basin, South-Central Washington. U.S. Geological Survey, Reston, Virginia.

Catchings RD and WD Mooney. 1988. Crustal structure of the Columbia Plateau: Evidence for continental rifting. Journal of Geophysical Research 93:459-474.

Chiou BS-J. and RR Youngs. 2006. Chiou and Youngs PEER-NGA Empirical Ground Motion Model for the Average Horizontal Component of Peak Acceleration and Pseudo-Spectral Acceleration for Spectral

Periods of 0.01 to 10 Seconds. Pacific Earthquake Engineering Research Center, University of California - Berkeley

Crider JG, RS Crosson, and J Brooks. 2003. The Chelan seismic zone, the Great Terrace and the December 1872 Washington State earthquake. Abstracts with Programs 35:645, Geological Society of America, Boulder, Colorado.

Farooqui SM and RC Thoms. 1980. Geologic Evaluation of Selected Faults and Lineaments, Pasco and Walla Walla Basins, Southeast Washington. Shannon \& Wilson, Inc., Richland, Washington.

Fecht KR, SP Reidel, and AM Tallman. 1987. Paleodrainage of the Columbia River system on the Columbia Plateau of Washington State - A summary. In Selected Papers on the Geology of Washington, JJ Schuster (ed), Bulletin 77, pp. 219-248. Washington State Department of Natural Resources, Division of Geology and Earth Resources, Olympia.

Fecht KR, KA Lindsey, BN Bjornstad, DG Horton, GV Last, and SP Reidel. 1999. Clastic Injection Dikes of the Pasco Basin and Vicinity. Geologic Atlas Series BHI-01103 Rev. 1, U.S. Department of Energy, Office of Environmental Restoration, Washington, D.C.

Finnegan NJ and DR Montgomery. 2003. Geomorphic and seismic evidence for recent deformation in the Yakima Fold Belt between Ellensburg and Yakima, WA. Abstracts with Programs 35:512, Geological Society of America, Boulder, Colorado.

Foundation Sciences, Inc. 1980. Geologic Reconnaissance of Parts of the Walla Walla and Pullman, Washington, and Pendleton, Oregon $1^{\circ} \times 2^{\circ}$ AMS Quadrangles. U.S. Army Corps of Engineers, Seattle, Washington.

Frankel AD, MD Petersen, CS Muller, KM Haller, RL Wheeler, EV Leyendecker, RL Wesson, SC Harmsen, CH Cramer, DM Perkins, and KS Rukstales. 2002. Documentation for the 2002 Update of the National Seismic Hazard Maps. Open-File Report 02-420, U.S. Geological Survey, Reston, Virginia. 
Garwood DL, JH Bush,, JD Kauffman, and TE Jones. 2003. New interpretations of structures in the Columbia River Basalt Group of the Clearwater Embayment, Idaho. Abstracts with Programs 35:551, Geological Society of America, Boulder, Colorado.

Geomatrix Consultants, Inc. 1988. Seismotectonic Evaluation of the Northern Cascade Mountains Geomorphic Province for Bumping Lake, Tieton, Keechelus, Kachess, Cle Elum, and Clear Creek Dams. Oakland, California.

Geomatrix Consultants, Inc. 1989. Seismotectonic Evaluation, Northwest Rocky Mountains-Okanogan Uplands Geomorphic Province. Oakland, California.

Glass CE. 1977. Remote sensing analysis of the Columbia Plateau. In WPPSS Nuclear Project No. 1, Washington Public Power Supply System Docket No. 50-460: Preliminary Safety Analysis Report, Amendment 23, v. 2B, Appendix 2R, Subappendix 2R K. Preliminary Safety Analysis Report, Washington Public Power Supply System, Richland, Washington.

Grolier MJ and JW Bingham. 1971. Geologic map and sections of parts of Grant, Adams and Franklin counties, Washington (1 sheet, scale 1:62,500). Geology Investigations Map I-589, U.S. Geological Survey, Reston, Virginia.

Hemphill-Haley M. Multi-Scaled Analyses of Contemporary Crustal Deformation of Western North America. PhD dissertation, University of Oregon, Eugene.

Idriss IM. 2007. Empirical Model for Estimating the Average Horizontal Values of Pseudo-Absolute Spectral Accelerations Generated by Crustal Earthquakes Volume 1 Sites with Vs30 $=450$ to 900 m/s. Pacific Earthquake Engineering Research Center, University of California, Berkeley.

Kienle CF Jr., ML Hamill, and DN Clayton. 1979. Geologic Reconnaissance of the Wallula Gap, Washington-Blue Mountains-La Grande, Oregon Region. Shannon \& Wilson, Inc., Richland, Washington.

Kuehn SC. 1995. The Olympic-Wallowa Lineament, Hite Fault System, and Columbia River Basalt Group Stratigraphy in Northeast Umatilla County, Oregon. M.S. thesis, Washington State University, Pullman.

Lacombe S, F Mouthereau, S Kargar, and B Meyer. 2006. Late Cenozoic and modern stress fields in the western Fars (Iran): Implications for the tectonic and kinematic evolution of central Zagros. Tectonics 25:TC1003.

Lidke DJ. 2002a. Fault number 562a, Saddle Mountains structures, Saddle Mountains fault. In Quaternary Fault and Fold Database of the United States - Version 1.0. Open-File Report 03-417, U.S. Geological Survey, Reston, Virginia. Available at http://qfaults.cr.usgs.gov.

Lidke DJ. 2002b. Fault number 562b, Saddle Mountains structures, folds and other faults of the Saddle Mountains. In Quaternary Fault and Fold Database of the United States - Version 1.0. Open-File Report 03-417, U.S. Geological Survey, Reston, Virginia. Available at http://qfaults.cr.usgs.gov.

Lidke DJ. 2002c. Fault number 563a, Umtanum Ridge structures, Central Gable Mountain fault. In Quaternary Fault and Fold Database of the United States - Version 1.0. Open-File Report 03-417, U.S. Geological Survey, Reston, Virginia. Available at http://qfaults.cr.usgs.gov. 
Lidke DJ. 2002d. Fault number 563b, Umtanum Ridge structures, folds and other faults of the Umtanum Ridge-Gable Mountain uplift. In Quaternary Fault and Fold Database of the United States - Version 1.0. Open-File Report 03-417, U.S. Geological Survey. Available at http://qfaults.cr.usgs.gov.

Lidke DJ. 2003a. Fault number 561a, Frenchman Hills structures, Frenchman Hills fault. In Quaternary Fault and Fold Database of the United States - Version 1.0. Open-File Report 03-417, U.S. Geological Survey, Reston, Virginia. Available at http://qfaults.cr.usgs.gov.

Lidke DJ. 2003b. Fault number 561b, Frenchman Hills structures, Lind Coulee fault. In Quaternary Fault and Fold Database of the United States - Version 1.0. Open-File Report 03-417, U.S. Geological Survey. Available at http://qfaults.cr.usgs.gov.

Lidke DJ. 2003c. Fault number 561c, Frenchman Hills structures, Folds and other faults of the Frenchman Hills uplift. In Quaternary Fault and Fold Database of the United States - Version 1.0. Open-File Report 03-417, U.S. Geological Survey, Reston, Virginia. Available at http://qfaults.cr.usgs.gov.

Lidke DJ. 2003d. Fault number 564a, Ahtanum Ridge structures, Ahtanum Creek fault. In Quaternary Fault and Fold Database of the United States - Version 1.0. Open-File Report 03-417, U.S. Geological Survey, Reston, Virginia. Available at http://qfaults.cr.usgs.gov.

Lidke DJ. 2003e. Fault number 564b, Ahtanum Ridge structures, folds and other faults of the Ahtanum Ridge uplift. In Quaternary Fault and Fold Database of the United States - Version 1.0. Open-File Report 03-417, U.S. Geological Survey, Reston, Virginia. Available at http://qfaults.cr.usgs.gov.

Lidke DJ and RC Bucknam. 2002. Fault number 566a, Toppenish Ridge structures, Mill Creek fault. In Quaternary Fault and Fold Database of the United States - Version 1.0. Open-File Report 03-417, U.S. Geological Survey, Reston, Virginia. Available at http://qfaults.cr.usgs.gov.

Lidke DJ and RC Bucknam. 2003. Fault number 566b, Toppenish Ridge structures, folds and other faults of the Toppenish Ridge uplift. In Quaternary Fault and Fold Database of the United States Version 1.0. Open-File Report 03-417, U.S. Geological Survey, Reston, Virginia. Available at http://qfaults.cr.usgs.gov.

Lidke DJ, SY Johnson, PA McCrory, SF Personius, AR Nelson, RL Dart, L-A Bradley, KM Haller, and MN Machette. 2003. Map and Data for Quaternary Faults and Folds in Washington State. Open-File Report 03-428, U.S. Geological Survey, Reston, Virginia. Available at http://pubs.usgs.gov/of/2003/428.

Ludwin RS, CS Weaver, and RS Crosson. 1991. Seismicity of Washington and Oregon. In Neotectonics of North America, DB Slemmons, ER Engdahl, MD Zoback, and DD Blackwell (eds). Decade Map 1:77-98, Geological Society of America, Boulder, Colorado.

Mann GM and CE Meyer. 1993. Late Cenozoic structure and correlations to seismicity along the Olympic-Wallowa Lineament, northwest United States. Geological Society of America Bulletin 105:853871.

McCaffrey R. 2001. GPS Velocity Field and Hazards Assessment for the Pacific Northwest. Collaborative research with Rensselaer Polytechnic Institute, University of Washington, and U.S. Geological Survey. Report 01HQ-GR-0026. Available at http://ees2.geo.rpi.edu/rob/www/gps/g0026.html. 
McCaffrey R. 2002. Crustal block rotations and plate coupling. In Plate Boundary Zones, Geodynamic Series 30, S Stein and J Freymueller (eds), pp. 101-122. American Geophysics Union, Washington, D.C.

McQuarrie N. 1993. Structural analysis of the Wallula Gap Fault, southeastern Washington. Abstracts with Programs 25:119, Geological Society of America, Boulder, Colorado.

Meghraoui M, R Jaegy, K Lammali, and F Albarede. 1988. Late Holocene earthquake sequences on the El Asnam (Algeria) thrust fault. Earth and Planetary Science Letters 90:187-203.

Miller MM, DJ Johnson, CM Rubin, H Dragert, K Wang, A Qamar, and C Goldfinger. 2001. GPSdetermination of along-strike variation in Cascadia margin kinematics: Implications for relative plate motion, subduction zone coupling, and permanent deformation. Tectonics 20:161-176.

Miller MM and DJ Johnson. 2002. Fate of the Eastern California shear zone along the Cascadia margin and entrainment of the Cascadia fore-arc in oblique subduction. Abstracts with Programs 34:A 106, Geological Society of America, Boulder, Colorado.

Miner A. 2002a. Seismicity and structure of the Columbia Basin: preliminary correlations. Abstracts with Programs, Cordillaren Section 98th Annual Meeting, Geological Society of America, Boulder, Colorado.

Miner A. 2002b. Eocene Tectonics and Active Deformation in Cascadia. MS thesis, Central Washington University, Ellensburg.

Ni JF and M Barazangi. 1986. Seismotectonics of the Zagros continental collision zone and a comparison with the Himalayas. Journal of Geophysical Research 91:8205-8218.

Ning Z and A Qamar. 2003. Seismicity and horizontal strain rate in the Pacific Northwest. Abstracts with Programs 35:582, Geological Society of America, Boulder, Colorado.

Personius SF and DJ Lidke. 2003a. Fault number 565, Rattlesnake Hills structures. In Quaternary Fault and Fold Database of the United States - Version 1.0. Open-File Report 03-417, U.S. Geological Survey, Reston, Virginia. Available at http://qfaults.cr.usgs.gov.

Personius SF and DJ Lidke. 2003b. Fault number 567, Horse Heaven Hills structures. In Quaternary Fault and Fold Database of the United States - Version 1.0. Open-File Report 03-417, U.S. Geological Survey, Reston, Virginia. Available at http://qfaults.cr.usgs.gov.

Personius SF and DJ Lidke. 2003c. Fault number 579, Luna Butte fault. In Quaternary Fault and Fold Database of the United States - Version 1.0. Open-File Report 03-417, U.S. Geological Survey, Reston, Virginia. Available at http://qfaults.cr.usgs.gov.

Personius SF and DJ Lidke. 2003d. Fault number 847, Arlington-Shutler Butte fault. In Quaternary Fault and Fold Database of the United States - Version 1.0. Open-File Report 03-417, U.S. Geological Survey, Reston, Virginia. Available at http://qfaults.cr.usgs.gov.

Piety A, RC LaForge, and LL Foley. 1990. Seismic Sources and Maximum Credible Earthquakes for Cold Springs and McKay Dams, Umatilla Project, North-Central Oregon. Seismotectonic Report 90-1, U.S. Bureau of Reclamation, Denver, Colorado. 
Prescott WH and JC Savage. 1984. Crustal Deformation near Hanford, WA. Open-File Report 84-797, U.S. Geological Survey, Reston, Virginia.

Reidel SP. 1984. The Saddle Mountains: the evolution of an anticline in the Yakima Fold Belt. American Journal of Science 284(8):942-978.

Reidel SP and KR Fecht. 1994. Geologic map of the Priest Rapids 1:100,000 quadrangle, Washington. Open File Report 94-13, Washington State Department of Natural Resources, Division of Geology and Earth Resources, Olympia.

Reidel SP, NP Campbell, KR Fecht, and KA Lindsey. 1994. Late Cenozoic structure and stratigraphy of south-central Washington. In Regional Geology of Washington, ES Cheney and R Lasmanis (eds), Washington Division of Geology and Earth Resources Bulletin 80, pp. 159-180. Washington State Department of Natural Resources, Division of Geology and Earth Resources, Olympia.

Reidel SP, KR Fecht, MC Hagood, and TL Tolan. 1989. The geologic evolution of the central Columbia Plateau.In Volcanism and Tectonism in the Columbia River Flood-Basalt Province, SP Reidel and PR Hooper (eds), pp. 247-264. Special Paper 239, Geological Society of America, Boulder, Colorado.

Reidel SP and NP Campbell. 1989. Guide to the structure of the Yakima Fold Belt. In Field Trips for the Geological Society of America Cordilleran and Rocky Mountain Sections Joint Meeting, Spokane, Washington,N Joseph (ed), pp. 275-304. Circular 86 (geologic guidebook for Washington and adjacent areas), Washington State Department of Natural Resources, Division of Geology and Earth Resources, Olympia.

Reidel SP and TL Tolan. 1994. Late Cenozoic structure and correlations to seismicity along the Olympic-Wallowa lineament, northwestern United States: Discussion. Geological Society of America Bulletin 106:1634-1638.

Repasky TR and NP Campbell. 1998. Earthquake Hazard Study in the Vicinity of Toppenish Basin, South-Central Washington. U.S. Geological Survey, Reston, Virginia.

Rigby JG and KL Othberg. 1979. Reconnaissance Surficial Geologic Mapping of the Late Cenozoic Sediments of the Columbia Basin, Washington. Open-File Report 79-3, Washington Department of Natural Resources, Division of Geology and Earth Resources, Olympia.

Rohay AC and JD Davis. 1983. Contemporary deformation in the Pasco Basin area of the central Columbia Plateau. In Preliminary Interpretation of the Tectonic Stability of the Reference Repository Location, Cold Creek Syncline, JA Caggiano and DW Duncan (eds). RHO-BW-ST-19P, Rockwell Hanford Operations, Richland, Washington.

Rohay A. 2003. Ongoing deformation and state of stress in the Columbia River flood basalts. Abstracts with Programs 35:136, Geological Society of America, Boulder, Colorado.

Sandness GA, CS Kimball, KE Schmeirer, and JW Lindberg. 1982. Report on Geologic Remote Sensing of the Columbia Plateau. PNL-3140, Pacific Northwest Laboratory, Richland, Washington.

Savage JC, M Lisowski, and WH Prescott. 1981. Geodetic measurements in Washington. Journal of Geophysical Research 86:4929-4940. 
Schuster EJ, CW Gulick, SP Reidel, KR Fecht, and S Zurenko. 1997. Geologic map of Washingtonsoutheast quadrant (2 sheets, scale 1:250,000). Geologic Map GM-45, Washington State Department of Natural Resources, Division of Geology and Earth Resources, Olympia.

Shaffer ME and MW West. 1989. Quaternary faulting in the Frenchman Hills anticline, Yakima fold belt, central Columbia Basin, Washington. Abstracts with Programs 21:142, Geological Society of America, Boulder, Colorado.

SSHAC (Senior Seismic Hazard Analysis Committee). 1997. Recommendations for Probabilistic Seismic Hazard Analysis: Guidance on Uncertainty and Use of Experts. NUREG/CR-6372, U.S. Nuclear Regulatory Commission, Washington, D.C.

Tabor RW, RB Waitt, VA Frizzell, Jr., DA Swanson, GR Byerly, and RD Bentley. 1982. Geologic map of the Wenatchee 1:100,000 quadrangle, central Washington. Miscellaneous Investigations Series Map I1311, U.S. Geological Survey, Reston, Virginia.

Tabor RW, VA Frizzell Jr., JA Vance, and CW Naeser. 1984. Ages and stratigraphy of lower and middle Tertiary sedimentary and volcanic rocks of the central Cascades, Washington: Application to the tectonic history of the Straight Creek fault. Geological Society of America Bulletin 95:26-44.

Tabor RW, VA Frizzell Jr., DB Booth, and RB Waitt. 2000. Geologic map of the Snoqualmie Pass $30 \mathrm{x}$ 60 minute quadrangle, Washington (scale 1:100,000). Geologic Investigations Series Map I-2538, U.S. Geological Survey, Reston, Virginia

Tolan TL and SP Reidel. 1989. Structure map of a portion of the Columbia River flood-basalt province (plate, scale 1:500,000). In Volcanism and Tectonism in the Columbia River Flood-Basalt Province, SP Reidel and PR Hooper (eds), Special Paper 239. Geological Society of America, Boulder, Colorado.

Tolan TL. 1982. The Stratigraphic Relationships of the Columbia River Basalt Group in the Lower Columbia River Gorge of Oregon and Washington. M.S. thesis, Portland State University, Portland, Oregon.

Tolan TL and MH Beeson. 1984. Intracanyon flows of the Columbia River Basalt Group in the lower Columbia River Gorge and their relationship to the Troutdale Formation. Geological Society of America Bulletin 95:463-477.

Tolan TL, NP Campbell, and KA Lindsey. 2004. 3D mapping of the Columbia River Basalt Group (CRBG) and the structural geology of the eastern Yakima fold belt (YFB) and the western Palouse slope: new structural features revealed and expanding the eastern limit of the YFB. Abstracts with Programs 36(4):34, Geological Society of America, Boulder, Colorado.

Walsh TJ, MA Korosec, WM Phillips, RL Logan, and HW Schasse. 1987. Geologic map of Washington - southwest quadrant (1:250,000). Geologic Map GM-34, Washington State Department of Natural Resources, Division of Geology and Earth Resources, Olympia.

WPPSS (Washington Public Power Supply System). 1981. Late Cenozoic tectonics of the Pacific Northwest with special reference to the Columbia Plateau. In Washington Public Power Supply System Nuclear Project Number 2, Final Safety Analysis Report, Amendment 18, Appendix 2.5N, pp. 2.5N-12.5N-44. Washington Public Power Supply System, Richland, Washington. 
WPPSS (Washington Public Power Supply System). 1982. Safety Evaluation Report Related to the Operation of WPPS Nuclear Project No. 2, Docket No. 50-397. Washington Public Power Supply System, Richland, Washington.

West MW. 1997. A Continuation of a "Pilot" Study of Quaternary Surface Deformation, Saddle Mountains Anticline, Northern Pasco Basin, Washington. U.S. Geological Survey, Reston, Virginia.

West MW, FX Ashland, AJ Busacca, GW Berger, and ME Shaffer. 1996. Late Quaternary deformation, Saddle Mountains anticline, south-central Washington. Geology 24(12):1123-1126.

West MW, AJ Busacca, GW Berger, ME Shaffer, and FX Ashland. 1994. A "Pilot” Study of Quaternary Surface Deformation, Saddle Mountains Anticline, Northern Pasco Basin, Washington. U.S. Geological Survey, Reston, Virginia.

West MW and ME Shaffer. 1988. Interim Draft Report - Probabilistic and Deterministic Seismotectonic Studies - O’Sullivan Dam and Potholes Reservoir, Washington. U.S. Bureau of Reclamation, Denver, Colorado.

West DO. 1987. The Wenas Valley fault - Holocene normal faulting or gravitational sliding in the Yakima Fold Belt, Columbia Plateau? Abstracts with Programs 19:463, Geological Society of America, Boulder, Colorado.

Wong I, M Hemphill-Haley, M Dober, and R Schapiro. 2002. Probabilistic Seismic Hazard Analyses Bumping Lake, Clear Creek, French Canyon, and Tieton Dams. U.S. Department of the Interior, Bureau of Reclamation, Denver, Colorado.

Yeats RS. 1986. Active faults related to folding. In Active Tectonics: Impact on Society, Geophysics Study Committee, Geophysics Research Forum, National Research Council, pp. 63-79. The National Academies Press, Washington, D.C.

Yeats RS, K Sieh, and CR Allen. 1997. The Geology of Earthquakes. Oxford University Press, New York. 

Appendix B

\section{Annotated Bibliography}





\section{Appendix B}

\section{Annotated Bibliography}

Relevant published documents are summarized in this appendix, with particular emphasis on any information pertinent to this topical report. The authors of this topical report made no interpretations of the original works. Although some raw data is included, most annotations focus on the authors' observations and interpretations of structural relationships. With the exception of the U.S. Geological Survey reports by Lidke, Personius, and Bucknam, all reports are primary sources. The documents annotated here are

Beanland and Berryman 1989

Bentley et al. 1980

Bruhn 1981

Campbell 1989

Campbell and Bentley 1981

Farooqui and Thoms 1980

Finnegan and Montgomery 2003

Jones and Oldow 2004

Lidke 2002a-d

Lidke 2003a-e

Lidke and Bucknam 2002a, b

Mann 1994

Mann and Meyer 1993

Mege and Reidel 2001

Meghraoui et al. 1988

Miller et al. 2001

Miner 2002

Personius and Lidke 2003a-d

Piety et al. 1990

Reidel and Tolan 1994

Reidel 1984

Reidel et al. 2005

Reidel et al. 1994

Rohay 2003

Shaffer and West 1989

Tolan et al. 2004

West 1997

West et al. 1996

West et al, 1994

Wong et al. 2002a

Yeats 1986

Yeats 2007 
Beanland S and KR Berryman. 1989. Style and episodicity of late Quaternary activity on the PisaGrandview Fault Zone, Central Otago, New Zealand: New Zealand Journal of Geology and Geophysics, vol. 32, pp. 451-461.

The Pisa-Grandview Fault Zone contains master faults that are continuous, as evidenced by Quaternary structures that extend through both Pisa and Grandview Faults. Faulting activity throughout the zone has varied both spatially and temporally over the Quaternary, occurring in clustered episodes. Despite assumed uniform tectonic stresses and regional uniformity in response to these stresses, individual faults are not simultaneously active. Rather, activity in a particular fault or fault set lasts for several tens of thousands of years, followed by several tens of thousands of years of inactivity. The magnitude of these intervals of time varies in different tectonic regions (i.e., New Zealand versus the Great Basin of the U.S.). Because activity moves sequentially between different faults, the faults and associated structures are likely connected, possibly by a décollement zone in the basement.

Bentley RD, JL Anderson, NP Campbell, and DA Swanson. 1980. Stratigraphy and Structure of the Yakima Indian Reservation, with Emphasis on the Columbia River Basalt Group. U.S. Geological Survey Open-File Report 80-200, 73 pp.

The Horse Heaven and Simcoe Mountains anticlines are part of the same uplift, divided by the Pine Creek syncline. Symmetry of the Simcoe anticline changes across a NW-trending strike-slip fault that is part of the Arlington-Shutler Butte fault. Displacement of the Simcoe anticline is greatest in the west. Most of the uplift is paralleled by complex splayed fault systems, which includes the Milk Ranch and Satus Creek fault systems. Displacement on the Milk Ranch fault decreases to the west. Lineaments are formed by normal cross faults, several of which divide the Simcoe anticline into en echelon segments. Faults and fracture systems also cross the Satus Basin, forming lineaments that occasionally stretch from the Horse Heaven-Simcoe uplift into Toppenish Basin. Toppenish uplift is divided into three segments (Hembre Mountain, Satus Peak, and Peavine) that are themselves be segmented and change geometry at NWtrending cross faults. The Hembre Mountain segment only shows Quaternary deformation in the far west. Late Quaternary surface rupture that is evident for $30 \mathrm{~km}$ starting at the eastern end of the Satus Peak segment and that includes up to 100 individual ruptures is interpreted as tectonic in origin. The Ahtanum Creek fault cuts the Tampico segment of the Ahtanum uplift. Sedge Ridge should be included in the main group of YFB uplifts, and shows what is likely Pliocene tilting in the west.

Bruhn RL. 1981. Preliminary Analysis of Deformation in Part of the Yakima fold belt, south-central Washington: Richland, Washington, Washington Public Power Supply System Report, 27 pp.

This is an older document, possibly written for WPPSS in response to work by Ed Price at Rockwell Hanford Operations. Bruhn looked at the style of folding and faulting on Umtanum Ridge and Gable Mountain, measuring strain and confirming that Umtanum Ridge is a kink-type fold. Based on his strain calculations from faulting, he estimated possible depths to a décollement surface for 2 different models, although he says a décollement is not required to accommodate the $\sim 10 \mathrm{~km}$ of shortening estimated by Laubscher. The fold detachment model preferred by Laubscher is probably not representative of YFB, calculated décollement depths were unreasonably deep or shallow and required the folds be symmetrical. The fault ramp model is more reasonable and explains the long gentle limb along with a steep limb, but can't account for all the variations in YFB folds. (Courtesy of M.A. Chamness) 
Campbell NP. 1989. Structural and Stratigraphic Interpretation of Rocks Under the Yakima Fold Belt, Columbia Basin, Based on Recent Surface Mapping and Well Data, in Reidel, S.P., and Hooper, P.R., eds., Volcanism and Tectonism in the Columbia River Flood-Basalt Province. Geological Society of America, Special Paper 239, pp. 209-222, Boulder, Colorado.

Folds in the Yakima fold belt (trending E-W) generally differ in orientation from folds in the deeper Jurassic-Miocene basement rocks. Exceptions are the White River-Naches River fault zone and Hog Ranch-Naneum Ridge, which, like the pre-basalt folds and Olympic-Wallowa lineament, trend NW-SE. Hog Ranch-Naneum Ridge crosses YFB anticlinal uplifts without offsetting them, and was active before and during CRBG eruption. The White River-Naches fault zone separates east-northeast-trending YFB folds from northwest-trending YFB folds, demonstrating influence on YFB fold development and the zone's continuation into the basalt. This fault zone occurs at the southern end of the Straight Creek fault, which splays in this location. These splays align with northwest-trending YFB folds, and one splay reaches through the basalt to form the Manastash fault. The Olympic-Wallowa lineament is aligned with structures in the prebasalt bedrock and may have relatively recently deformed the Manastash fault, and Umtanum, Yakima, and Rattlesnake ridges. Folds in the basalts are tighter and more closely spaced in the interior of the YFB and Columbia Basin, becoming more gently dipping toward the margin of this region. Where deeper and shallower folds are parallel, this difference in fold shape at the margin may be due to distribution of shear over many smaller faults that are not easily visible. In the case of folds trending in opposite directions, gentle folds along the margin could be due to a décollement somewhere above the pre-basalt rocks.

Campbell NP and RD Bentley. 1981. Late Quaternary Deformation of the Toppenish Ridge Uplift in South-Central Washington. Geology, vol. 9, pp. 519-524.

Satus Peak, a section of Toppenish Ridge, is the only Yakima fold showing abundant surface ruptures originating in the late Quaternary. Sag pond bottom material on the peak's slope is dated at 500-600 yr, and faults cut through many Quaternary sediments. Mount St. Helens "set S" tephra (13 ka) constrain the lower age date of another set of faults. Quaternary landslide distribution is partially attributed to rupture location. There are three sets of ruptures grouped by location on the peak- the crestal, hinge, and fan sets. The former two are a result of extension, the latter likely due to slip along an older thrust fault and suggesting a décollement. The anticline also contains large displacement faults of an older age.

Farooqui SM and RC Thoms. 1980. Geologic evaluation of selected faults and lineaments, Pasco and Walla Walla Basins, southeast Washington: Shannon and Wilson, Inc., prepared for the Washington Public Power Supply System.

Seven less well studied potential faults are examined. The main north fault in the Finley Quarry fault zone has experienced late Pleistocene movement no younger than $7 \mathrm{Ka}$. The Kennewick-Cold Creek lineament parallels the RAW but appears to be erosional in origin. The base of a Pleistocene loess unit is cut by the Buroker fault, which is a N-S striking reverse fault. Field studies of a supposed Game Farm Hill fault indicate there is no evidence of faulting in this area. The Silver Dollar fault is a reverse or normal fault in Yakima Ridge basalts, and decreases in displacement toward the east. Tight fold geometry and presence of an escarpment suggest that, if it does exist, the Badger Mountain fault is confined to the SE Hill of Badger Mountain. Evidence for the presence of a Badger Canyon fault is speculative. 
Finnegan NJ and DR Montgomery. 2003. Geomorphic and seismic evidence for recent deformation in the Yakima fold belt between Ellensburg and Yakima, WA: Geological Society of America Abstracts with Programs, vol. 35, no. 6, p. 512.

The Yakima Ridge and Umtanum Ridge anticlines are incised by the Yakima River or its tributaries at a relatively high angle. As indicated by this geomorphic evidence and the recorded locations of earthquake hypocenters, the two anticlines are active, high-angle thrust faults. This can be supported despite the lack of evidence for recent deformation. Earthquake hypocenter clusters are E-W oriented.

Johnson PA. 1989. Central Washington Seismicity: Evidence for a Reactivated Buried Continental Rift and Northwest-Trending Structural Zones. Geophysical Research Letters, vol. 16, no. 11, pp. $1325-1328$.

Clustering of microseismicity in the Yakima fold belt varies in geographic distribution between the shallower Columbia River basalt and the deeper basement. Shallow clustering occurs near Chelan, WA, just to the northeast of the Entiat fault. In contrast to other studies which repeatedly indicate north-south compression as the cause for YFB structural development, focal mechanisms of this earthquake cluster suggests northwest-southeast compression. The Corfu seismic belt composes the second shallow cluster, with earthquakes here often occurring in swarms. A west-trending alignment of epicenters in this seismic belt is likely related to the Saddle Mountains fault. Seismic clusters also occur in rock deeper than $10 \mathrm{~km}$. Deep and shallow earthquake hypocenters are influenced by the underlying rift graben. Because of the proximity and dip of the Chiwaukum graben, this rift graben is interpreted to be an extension of the Chiwaukum graben. Additionally, YFB seismicity may be related to the buried continental rift, which could act as a structural control dictating the location of seismic clusters. Rifting may have weakened local crust, increasing the likelihood that stress is relieved along nearby structures. The Straight Creek fault system may also influence the westernmost cluster of seismicity.

Jones TE and JS Oldow. 2004. Transition from active basin and range extension to contraction and block rotation, Blue Mountains, northeast Oregon, southeast Washington, and western Idaho: Geological Society of America Abstracts with Programs, vol. 36, no. 4, p. 28.

Stresses due to a clockwise rotation of the Blue Mountains block, with a pole located near Orofino, ID, are accommodated by formation of the YFB. This movement results in a decrease in contractional strain to the east in the NE Blue Mountains.

Note: the change in strain experienced by the Blue Mountains may influence changes in stress along the southern YFB margin.

Lidke DJ, compiler. 2002. Fault number 562a, Saddle Mountains structures, Saddle Mountains fault, in Quaternary Fault and Fold Database of the United States: U.S. Geological Survey website, http://earthquakes.usgs.gov/regional/qfaults.

Most faults associated with the Saddle Mountains anticline do not show definite Quaternary deformation. However, the Saddle Mountains structures, including the Saddle Mountains faults and related normal faults, do show Quaternary offset. These structures are east-trending, and the normal faults may be due to tension originating in movement on the underlying Saddle Mountains thrust fault. Late Pleistocene to Holocene sediments are displaced $1.3 \mathrm{~m}$, and additional Pleistocene offset is also recorded. Normal faults and a graben formed over the past $100 \mathrm{kyr}$ are located in the Smyrna Bench area. Development of grabens, beheading of streams, and creation of sag ponds indicate Quaternary movement. Within the graben, scarps formed by loess landslides due to uphill fault ruptures are dated to less than $6.85 \mathrm{ka}$. Also within the graben, a paleosol with a slip of at least $13 \mathrm{~m}$ is dated to between 20 and $40 \mathrm{ka}$. However, 
because it is uncertain whether the Saddle Mountain fault and Smyrna Bench graben are directly connected, the fault's age of most recent activity can only be constrained to within the past $130 \mathrm{kyr}$. The Saddle Mountains fault is trenched.

Lidke DJ, compiler. 2002. Fault number 562b, Saddle Mountains structures, folds and other faults of the saddle Mountains, in Quaternary Fault and Fold Database of the United States: U.S. Geological Survey website, http://earthquakes.usgs.gov/regional/qfaults.

For details regarding the Saddle Mountains structures and fault, see annotation for Fault 562a. While the Saddle Mountain fault and associated normal faults have been active as recently as the Holocene, the remaining faults in the area show no evidence of Quaternary movement. However, Quaternary deposits are rare. Deformation along these structures, which are primarily the Saddle Mountain anticline and related thrust faults, appears to only affect Miocene and Pliocene rocks. The Saddle Mountain anticline, itself a compound fold, is likely connected to the Crest anticline and monocline. Folds in the Saddle Mountain anticline formed during northward reverse-thrust movement.

Lidke DJ, compiler. 2002. Fault number 563a, Umtanum Ridge structures, Central Gable Mountain fault, in Quaternary Fault and Fold Database of the United States: U.S. Geological Survey website, http://earthquakes.usgs.gov/regional/qfaults.

For details regarding the Umtanum Ridge-Gable Mountain structures, see annotation for Fault 563b. The Central Gable Mountain fault is a northeast-striking oblique-slip fault cutting almost perpendicular to the east-striking anticlinal uplift of the Umtanum Ridge, Gable Mountain, and Gable Butte. Latest Pleistocene activity has resulted in about $6 \mathrm{~cm}$ of offset along the central Gable Mountain fault, with a total of $60 \mathrm{~m}$ offset starting in the Miocene. Only the bottom portion of glacial flood deposits (19 to $13 \mathrm{ka})$ are offset. The fault has been trenched and drilled by NESCO.

Lidke DJ, compiler. 2002. Fault number 563b, Umtanum Ridge structures, folds and other faults of the Umtanum Ridge-Gable Mountain uplift, in Quaternary Fault and Fold Database of the United States: U.S. Geological Survey website, http://earthquakes.usgs.gov/regional/qfaults.

Located in the central to northern portion of the YFB, the Umtanum Ridge-Gable Mountain structures are divided into two segments, based on evidence of Quaternary activity. The east-striking anticlinal uplift expressed as the hills and ridges of Umtanum Ridge, Gable Butte, and Gable Mountain shows no evidence of Quaternary displacement.

Uplift is associated with thrust and reverse faults. Both northern and southern limbs of the uplift possess east-striking thrust faults. The second segment, that of the Central Gable Mountain fault, is northeast striking, cuts across the axial trend of the east-striking uplift, and has experienced $6 \mathrm{~cm}$ of reverse offset during the past 13 to $19 \mathrm{kyr}$. This fault's recent activity suggests that other structures within the Umtanum Ridge-Gable Mountain area may also have been active during the late Quaternary. Evidence for relatively recent faulting may be concealed by late Quaternary gravel and dune deposits, and landslides are the source of scarps in the area. Despite the possible difference in age of most recent activity, the structures are considered to be part of a single anticlinal ridge. Exposed thrust faults in the Umtanum Ridge area are thought to be connected to a thrust fault buried in the Gable Mountain and Gable Butte area. The main fault in the uplift has a recurrence rate of between 940 and $51.4 \mathrm{kyr}$, with a slip rate of between 0.0032 and $0.0046 \mathrm{~mm} / \mathrm{yr}$. If Quaternary slip has occurred, lack of fault scarps indicates a low slip rate. 
Lidke DJ, compiler. 2003. Fault number 561a, Frenchman Hills structures, Frenchman Hills fault, in Quaternary Fault and Fold Database of the United States: U.S. Geological Survey website, http://earthquakes.usgs.gov/regional/qfaults.

Located in the northeastern YFB, the $51 \mathrm{~km}$-long Frenchman Hills fault section of the Frenchman Hills structures refers to faults and fault-features on the northern side of the Frenchman Hills and Frenchman Hills anticline. Quaternary displacement is evident in this section and the Lind Coulee fault section, but not in the remaining faults and folds associated with the Frenchman Hills anticlinal uplift. Even within the Frenchman Hills fault, Quaternary displacement may not have occurred in the far western portion. Presence and location of fault lineaments is debated, but some lineaments may indicate late Quaternary displacement of flood deposits. The Frenchman Hills thrust fault is south-dipping, and cuts the north limb of the anticlinal uplift.

Lidke DJ, compiler. 2003. Fault number 561b, Frenchman Hills structures, Lind Coulee fault, in Quaternary Fault and Fold Database of the United States: U.S. Geological Survey website, http://earthquakes.usgs.gov/regional/qfaults.

A combined $4 \mathrm{~km}$ in length, the Lind Coulee faults are east striking, south-dipping faults to the south and southeast of the Potholes Reservoir. These thrust faults cut the northern limb of the Lind Coulee flexure. Age of most recent activity is uncertain, but likely falls between $790 \mathrm{ka}$ and 40-50 ka. Glacial outburst floods have eroded scarps along fault lines.

Lidke DJ, compiler. 2003. Fault number 561c, Frenchman Hills structures, folds and other faults of the Frenchman Hills uplift, in Quaternary Fault and Fold Database of the United States: U.S. Geological Survey website, http://earthquakes.usgs.gov/regional/qfaults.

Excepting the Frenchman Hills fault and Lind Coulee fault, the Frenchman Hills anticline and related folds and faults show no deformation younger than Miocene age. The anticline is east-trending and is composed of three segments- West Canal, Powder Ranch, and Lind Coulee. Associated folds and faults continue west beyond the Frenchman Hills and are likely continuations of structures within the hills. Sense of movement is thrust, and while evidence of deformation of Quaternary sediments is absent, those sediments are sparse here. A lack of scarps suggests that if Quaternary movement has occurred, uplift rate is very small.

Lidke DJ, compiler. 2003. Fault number 564a, Ahtanum Ridge structures, Ahtanum Creek fault, in Quaternary Fault and Fold Database of the United States: U.S. Geological Survey website, http://earthquakes.usgs.gov/regional/qfaults.

In the west to central YFB, the Ahtanum Ridge structures are divided into two sections- the buried Ahtanum Creek thrust fault and normal faults in a graben south of this fault have experienced Quaternary movement, and compose one $18 \mathrm{~km}$ section. The remaining Ahtanum Ridge structures compose the second, $60 \mathrm{~km}$-long section. Scarps and the graben structure of the Ahtanum Creek fault are somewhat similar to the Mill Creek fault structures. Scarps on the steep limb of the anticline are similar in location to thrust faults on other YFB anticlines. The Ahtanum Creek fault is east-striking and located at the base of the anticlinal ridge. No surface exposure is evident, and the fault is overlain by late Pleistocene and Holocene loess and landslide deposits. However, faults within the associated graben are likely a result of movement on the underlying Ahtanum Creek fault. These graben faults show two to three offsets, dated to $12-41 \mathrm{ka}, 41-95 \mathrm{ka}$, and 95-109 ka. Tephra dated at $13 \mathrm{ka}$ is no disturbed. 
Lidke DJ, compiler. 2003. Fault number 564b, Ahtanum Ridge structures, folds and other faults of the Ahtanum Ridge uplift, in Quaternary Fault and Fold Database of the United States: U.S. Geological Survey website, http://earthquakes.usgs.gov/regional/qfaults.

This section of the Ahtanum Ridge structures, including north- to northwest-striking faults and eaststriking anticline segments underlain by east-striking thrust-reverse faults, does not show evidence of Quaternary deformation. The Ahtanum Ridge uplift is composed of two segments- the Tampico and Cowboy Parking Lot anticlines- and appears to join or merge with the Rattlesnake Hills uplift. Eaststriking thrust faults occur on both the northern and southern limbs of the Ahtanum Ridge uplift. Most recent deformation may be hidden by late Quaternary loess, landslides, and alluvial fans. The latest confirmed deformation occurred during the Miocene.

Lidke DJ and RC Buckman, compilers. 2002. Fault number 566a, Toppenish Ridge structures, Mill Creek fault, in Quaternary Fault and Fold Database of the United States: U.S. Geological Survey website, http://earthquakes.usgs.gov/regional/qfaults.

Within the Toppenish Ridge structures of the south-central YFB, the Mill Creek thrust fault and subsidiary normal faults are considered one section. The Toppenish Ridge anticline and remaining folds and faults compose the second section. The Mill Creek fault is south-dipping and cuts the northern limb of the Toppenish Ridge uplift. Only about $24-34 \mathrm{~km}$ of the $60 \mathrm{~km}$ long, mostly buried Mill Creek thrust fault shows evidence of Quaternary offset. This segment is within the Satus Peak area, and displays at least 100 surface ruptures, as well as many fault scarps. Tephra dated to $13 \mathrm{ka}$, and soils dated to 6.7 and $5.7 \mathrm{ka}$ are disturbed by tectonic activity. Ruptures have disrupted drainage and created sag ponds, the bottom of which are dated to 600-700 ybp. Although presence of some past seismic events, there is evidence for three to five events within the past $180 \mathrm{ka}$. The fault is trenched.

Lidke DJ and RC Buckman, compilers. 2002. Fault number 566b, Toppenish Ridge structures, folds and other faults of the Toppenish Ridge uplift, in Quaternary Fault and Fold Database of the United States: U.S. Geological Survey website, http://earthquakes.usgs.gov/regional/qfaults.

This section of the Toppenish Ridge structures includes the Toppenish Ridge anticline and related folds and faults that only show obvious displacement of Miocene and Pliocene rocks. The structures are easttrending and are located in the south to central YFB. The anticline, though continuous, can be divided into three segments - the Peavine Ridge, Satus Peak, and Hembre Mountain. Toppenish and Peavine Ridges are nearly connected. East-striking thrust faults occur on both the northern and southern limbs of the uplift, and the anticline overlies a principle thrust fault. Quaternary displacement is not evident anywhere besides on the Satus Peak section.

Mann GM. 1994. Late Cenozoic structure and correlation to seismicity along the Olympic-Wallowa Lineament, northwestern United States: Reply: Geological Society of America Bulletin, vol. 106, pp. 1639-1641.

Magnetic anomalies on the Ice Harbor zone of the WFZ have a positive polarity, whereas anomalies on the Walla Walla Plateau are negatively polarized- these anomalies cannot be connected. The WFZ exhibits strong localized extension 10-15 degrees within the E-W minimal stress direction, supporting the duplex model. There are structural connections between the RAW and WFZ, and therefore activity in either implies potential activity in the other.

Mann GM and CE Meyer. 1993. Late Cenozoic structure and correlations to seismicity along the Olympic-Wallowa Lineament, northwest United States: Geological Society of America Bulletin, vol. 105, pp. 853-871. 
Like other NW-trending fault zones in the NW Cordillera, the Olympic-Wallowa Lineament (OWL) is probably a right-slip fault system accommodating eastern basin-and-range extension. A 1936 earthquake of magnitude 6.1 occurred in the Wallula fault zone (WFZ), the section of the OWL passing through the Columbia Plateau. The WFZ is a right-slip extensional duplex. Surface features in several areas throughout the OWL are a result of basement right-slip fault zones- for instance, a 'disrupted zone' fault segments in the Long Valley fault system. The OWL experiences an abrupt change in structural style when crossing a crustal boundary at Wallula gap, perhaps due to a change in basalt thickness. Like this crustal boundary, the Kennewick lineament possesses a magnetic anomaly. Holocene faulting may be recorded in Kennewick lineament sediments and appear to branch out from this structure. Earthquake hypocenters (2-5 km deep) and anticlinal structure west of Wallula Gap suggest a progressive crustal detachment in the area. Because the WFZ is historically active and the Rattlesnake-Wallula alignment (RAW) runs parallel to the WFZ, it is likely that the RAW is also active.

Mége D and SP Reidel. 2001. A method for estimating 2D wrinkle ridge strain from application of fault displacement scaling to the Yakima folds, Washington: Geophysical Research Letters, vol. 28, no. 18 , pp. $3545-3585$.

Most YFB ridges are divided into strongly linked segments. Displacement rates on a single ridge can highly vary, but can also remain approximately constant for millions of years.

Meghraoui M, R Jaegy, K Lammali, and F Albarede. 1988. Late Holocene earthquake sequences on the El Asnam (Algeria) thrust fault: Earth and Planetary Science Letters, vol. 90, pp. 187-203.

The El Asnam fault zone is located in a synclinal valley and experienced a $\mathrm{M}=7.3$ earthquake in 1980 . This earthquake resulted in colluvial wedge scarps, fault displacement, secondary extensional structures, and flooding- the abundant sedimentary deposits also record older Holocene earthquakes. Activity may not be recorded in the non-cohesive surface material, which normal faults cannot pass through. Secondary normal faults can be produced at the surface due to a bending-moment of soft surface sediments. Existing surficial evidence of buried fault scarps includes bent layers, thickened sediments and normal faults. In this area, generally same-size earthquakes occur in clusters between relatively long periods of inactivity. Although smaller seismic events occur, surface ruptures are only produced when $M>7$, and these ruptures occur along the entire length of the fault. Here, main segments of the fault have experienced approximately the same number of faulting events.

Miller MM, DJ Johnson, CJ Rubin, H Dragert, K Wang, A Qamar, and C Goldfinger. 2001. GPSdetermination of along-strike variation in Cascadia margin kinematics: Implications for relative plate motion, subduction zone coupling, and permanent deformation: Tectonics, vol. 20, issue 2, pp. 161-176.

In eastern Washington between Lind and Goldendale, present-day shortening is about $1 \mathrm{~mm} / \mathrm{yr}$, which fits with low but active contraction in the YFB. Seismicity in the YFB is diffuse and earthquakes have not been attributed to any individual faults. Small strain is also visible in the OWL, the southern portion of which possesses evidence for Quaternary dextral and normal-oblique displacement. Data originates from continuous GPS records.

Miner AM. 2002. Seismicity and structure of the Columbia Basin: preliminary correlations: Geological Society of America, Abstracts with Programs.

A décollement controls the YFB, while some faults in other areas of the Columbia Basin are connected to the basement. Earthquakes cluster on axial surfaces in the YFB. Fold complexity is due to secondary 
kink and fault-bend folding, and relatively deep stress is accommodated by distributed strain. Some sinistral slip due to regional NNE contraction likely occurs on reverse faults underlying the YFB anticlines. Radially-directed strain is present at the margins of the Columbia Basin.

Personius SF and DJ Lidke, compilers. 2003. Fault number 847, Arlington-Shutler Butte fault, in Quaternary fault and fold database of the United States: U.S. Geological Survey website, http://earthquakes.usgs.gov/regional/qfaults.

At the southern end of the Yakima Fold Belt (YFB), the Arlington-Shutler Butte fault is a northwesttrending fault zone cutting across older eastward-trending folds and faults. Displacement occurs on only some of these older faults. Arlington-Shutler faults are right-lateral vertical strike-slip and normal. Most recent activity occurred $780 \mathrm{ka}$ or later, and while no deformation in Quaternary deposits is visible, this does not preclude Quaternary faulting. Slip rates are likely between 0.01 and $0.1 \mathrm{~mm} / \mathrm{yr}$.

Personius SF and DJ Lidke, compilers. 2003. Fault number 579, Luna Butte fault, in Quaternary fault and fold database of the United States: U.S. Geological Survey website, http://earthquakes.usgs.gov/regional/qfaults.

The Luna Butte fault is located in the Klickitat County, in the southern YFB, and is a northwest-trending fault zone composed of vertical, right-lateral strike-slip and normal faults, with a subsidiary thrust splay. The Luna Butte fault crosses east-trending structures, only some of which are displaced. Most recent faulting occurred less than $750 \mathrm{Ka}$, as judged by geomorphic preservation of faulting. Slip rates are likely between 0.01 and $0.1 \mathrm{~mm} / \mathrm{yr}$.

Personius SF and DJ Lidke, compilers. 2003. Fault number 567, Horse Heaven Hills structures, in Quaternary fault and fold database of the United States: U.S. Geological Survey website, http://earthquakes.usgs.gov/regional/qfaults.

Located in the southern portion of the YFB, the exceptionally long set of Horse Heaven Hills structures are composed of two segments- one trending northwest and the other northeast. Both segments are expressed as north-verging anticlines with the north and south limbs of the fold cut by northwest- and northeast-striking thrust faults. Uplift along the Horse Heaven Hills folds slowed in stages since initiation around $17 \mathrm{Ma}$. There is no definite evidence of Quaternary faulting, but most recent activity was likely after 1.6 Ma. A recurrence interval of between 390 and $50 \mathrm{kyr}$ for displacement events of 0.02 to $1.0 \mathrm{~m}$ has been proposed. Quaternary loess deposits, which cover much of the Hills, show possible scarps aging less than $100 \mathrm{ka}$. Landslide deposits are also very common.

Personius SF and DJ Lidke, compilers. 2003. Fault number 565, Rattlesnake Hills structures, in Quaternary Fault and Fold Database of the United States: U.S. Geological Survey website, http://earthquakes.usgs.gov/regional/qfaults.

The Rattlesnake Hills structures, while not definitively connected to the adjacent Wallula fault system, is part of the northwest-trending Rattlesnake-Wallula (RAW) lineament in the central and southeastern YFB. The Hills structures extend laterally for about $60 \mathrm{~km}$, and are expressed as en echelon anticlinal segments overlying south- or southwest-trending high-angle thrust or reverse faults. Both north and south limbs of the anticlines are cut by east- and northwest-striking thrust faults. Quaternary loess, landslide deposits, and glacial outburst flood deposits cover much of the Hills. Most recent activity occurred less than 1.6 Ma, but no definitive deformation of Quaternary sediments has been identified. It is possible that tightening of folds in this area has occurred during the Quaternary. Uplift rates suggest that the structures have a recurrence interval of between 250 and $12.5 \mathrm{kyr}$ for displacement events of 0.02 to $1.0 \mathrm{~m}$. If the structures are still active, they have a relatively low $(<0.145 \mathrm{~mm} / \mathrm{yr})$ slip rate. 
Piety LA, RC LaForge, and LL Foley. 1990. Seismic sources and maximum credible earthquakes for Cold Springs and McKay dams, Umatilla Project, north-central Oregon: U.S. Bureau of Reclamation Seismotectonic Report 90-1, 62 pp.

Seismic activity in the Columbia Plateau is diffuse and variable, with occasional shallow swarms. A structure is here considered a potential seismic source if it possesses late Quaternary $(<125 \mathrm{Ka})$ surface deformation or surface deformation of an unknown age. Additionally, microseismicity indicates continuing N-S compression in the YFB, and the YFB's structures and tectonic setting are similar to other historically active fold belts. This leads to the conservative conclusion that even anticlines without surface scarps are potential seismic sources. Synclines in the YFB do not possess seismogenic faults. The Horse Heaven Hills and Columbia Hills anticlines should be given similar values for a maximum credible earthquake as Toppenish Ridge, based on the similarity in anticlinal length. Furthermore, because only a portion of Toppenish Ridge and Saddle Mountains is active, it is assumed that only a portion of the Horse Heaven Hills is active. A section up to $58 \mathrm{~km}$ long on the Columbia Hills may have Quaternary displacement, so this section is considered a potential seismic source. Although connection of YFB faults and folds to deeper faults is debated, the El Asnam earthquake indicates that regardless of a deeper connection, seismic hazard remains large. Stress direction has changed in the YFB, resulting in differences in orientation between younger displacements and the older structures on which they formed. Also, different types of displacement formed at different times. Direction of stress possibly changes with depth. Anticlines in the southern YFB are relatively varied in orientation, and while they do not show surface faulting, it is assumed they have the same type of underlying thrust to reverse faults as similarlyshaped folds in the northern YFB. The number and continuity of cross faults dividing anticlinal uplifts into segments increases from east to west. Some interaction between different stress regimes (i.e., N-S compression in the Columbia Plateau and E-NE extension in north-central Oregon) may be evident toward the edge of the Plateau.

Reidel SP and TL Tolan. 1994. Late Cenozoic structure and correlation to seismicity along the Olympic-Wallowa Lineament, northwestern United States: Discussion: Geological Society of America Bulletin, vol. 106, pp. 1634-1648.

The OWL is not a single, continuous structure. Mann and Meyer's duplex model of the Wallula Fault Zone is incorrect, and this zone has little or no strike-slip. Magnetic anomalies surrounding the Kennewick-Cold Creek lineament are a result of basalt-cored anticlines, and the lineament is a break in slope from flood terraces.

Reidel SP. 1984. The Saddle Mountains: The evolution of an anticline in the Yakima Fold Belt: American Journal of Science, vol. 284, pp. 942-978.

The Saddle Mountains compose an anticlinal ridge that can be divided into six segments based on fold geometry. A high-angle reverse or thrust fault, the Saddle mountains fault, has caused displacement of at least $2.5 \mathrm{~km}$ along the ridge. Secondary tectonic structures are present on the Saddle Mountains. The Smyrna anticline and Hog Ranch-Naneum Ridge anticline extend beyond the anticlinal uplift. Local thrust faults occur near Saddle Gap and are common west of Sentinel Gap. Distinct fault zones are present on the Saddle Mountains, which are also modified by a northwest-trending shear system. Uplift rate has slowed since the early Miocene. Frequent, low-magnitude displacements during continuous deformation are indicated by lack of fault scarps and presence of folded basalts and sediments. Different areas of the Saddle mountains fault show deformation of different ages. Uplift probably occurred in stages, marked by changes in growth rate. Because other YFB anticlinal folds indicate similar ages and rates of growth, the Saddle Mountains can act as a model for these other folds. This model is consistent with the known Columbia Plateau tectonic context. Furthermore, similarity between age and supply of 
the Columbia River Basalt Group and the growth rate of the Saddle Mountains indicates that the YFB and CRBG are caused by the same tectonic processes. Shallow earthquake swarms in the area indicate persisting growth. Segments of the Saddle Mountains may be partially controlled by basement structures and reactivation of basement faults, and the Hog Ranch-Naneum Ridge anticline is directly connected to basement structures.

Reidel SP, J Bush, D Garwood, J Kauffman, and BS Martin. 2005. The tectonic evolution of the northern Columbia River flood-basalt province: Geological Society of America Abstracts with Programs, vol. 37, no. 7, p. 126.

Subsidence during basalt eruption formed basins at the boundary of the continental craton and accreted terrains. In the YFB, fold growth, subsidence, basalt eruption, and pole rotation have closely correlated rates.

Reidel SP, NP Campbell, KR Fecht, and KA Lindsey. 1994. Late Cenozoic structure and stratigraphy of south-central Washington: Washington Division of Geology and Earth Resources Bulletin, vol. 80, pp. 159-180.

The OWL is parallel to but not connected to basement structures, and causes change in ridge trends from Manastash Ridge to Rattlesnake Mountain. In general, the trends of anticlines reflect the trends of the areas they cross. Folds in the YFB are north-verging with the exception of some anticlines including Columbia Hills, Cleman Mountain, and other anticlinal segments, which are south-verging. The boundary between Saddle Mountains segments Eagle Lake and Saddle Gap occurs above the suture zone between the continental craton and accreted terranes. The Hog-Ranch-Naneum Ridge anticline may not, as was previously thought, be connected to the basement. In the YFB, evidence for continued displacement is generally only present in frontal fault zones. Quaternary faulting appears equally distributed in CLEW and non-CLEW regions, and fold belt development has likely been evenly distributed since the Miocene. Although stresses are evenly distributed, seismicity is concentrated in the YFB's competent synclines, for movement in the incompetent anticlines can occur aseismically. The Saddle Mountains fault is the only YFB fault known to be associated with seismicity.

Reidel SP, KR Fecht, MC Hagood, and TL Tolan. 1989. The Geologic Evolution of the Central Columbia Plateau, in Reidel, S.P., and Hooper, P.R., eds., Volcanism and Tectonism in the Columbia River Flood-Basalt Province. Geological Society of America, Special Paper 239, pp. 247-264, Boulder, Colorado.

Ridges in the eastern and central portion of the YFB are more closely spaced than ridges to the west, and ridges within the CLEW are the most closely spaced. Anticlinal trends - such as those of the Yakima and Umtanum Ridges - change direction when crossing the CLEW, and the Yakima Ridge decreases in structural relief in this area. For most frontal faults in the YFB, as anticlinal structural relief decreases, the fault itself dies out. Because crustal shortening in the YFB is small, the CRBG is more likely connected via local or limited décollements than via a regional décollement.

Rohay AC. 2003. Ongoing deformation and state of stress in the Columbia River flood basalts: Geological Society of America Abstracts with Programs, vol. 35, no. 6, p. 136.

Maximum compressive stress in both the YFB and sub-basalt rocks is in the N-S direction. A switch from minimum compressive stress in a vertical to a E-W direction in the western YFB allows for a component of right-lateral strike slip movement. Seismicity in the YFB occurs mostly as earthquake swarms with micro-earthquakes that increase in frequency and magnitude during the swarming event. This pattern may be due to clusters of events occurring within individual basalt layers, and are separated 
physically and temporally by weaker layers. Because strength and thickness of units underlying basalt likely affect stresses within the basalt, stresses in the northern YFB may be influenced by the proximity of the basement.

Shaffer ME and MW West. 1989. Quaternary faulting in the Frenchman Hills anticline, Yakima Fold Belt, central Columbia Basin, Washington: Geological Society of America Abstracts with Programs, vol. 21, p. 142.

The Frenchman Hills anticline, northernmost fold in the YFB, shows faulting of Ringold sediments, which have been displaced about $4.5 \mathrm{~m}$. Loess (older than $790 \mathrm{ka}$ ) and paleosols above the Ringold Formation are also faulted, but glacial flood deposits (about 40 to $50 \mathrm{ka}$ ) are not. Timing of tectonic activity is thus constrained, but only in so far as these dates are accurate.

Tolan TL, NP Campbell, and KA Lindsey. 2004. 3D mapping of the Columbia River Basalt Group (CRBG) and the structural geology of the eastern Yakima fold belt (YFB) and the western Palouse slope: new structural features revealed and expanding the eastern limit of the YFB: Geological Society of America Abstracts with Programs, vol. 36, no. 4, p. 34.

The Saddle Mountains anticline extends $16 \mathrm{~km}$ east of what was previously thought as its maximum length, and the Frenchman Hills extends an additional $32 \mathrm{~km}$. Two buried anticlinal YFB folds have been discovered below Quincy Basin. Two en echelon NW-trending brachyanticlines have been newly identified in the RAW. Definition of either the Hanson Creek structure or Sentinel Gap should be extended to include a fold found S of Sentinel Gap.

Watters TR. 1989. Periodically spaced anticlines of the Columbia Plateau, in Reidel, S.P., and Hooper, P.R., eds., Volcanism and Tectonism in the Columbia River Flood-Basalt Province. Geological Society of America, Special Paper 239, pp. 283-292, Boulder, Colorado.

Regularly spaced anticlinal ridges of the YFB can be divided into three domains based on ridge spacing and orientation. These include a) the northern domain, which is composed of eastern Umtanum Ridge, Saddle Mountains, and Frenchman Hills, b) the central domain with Rattlesnake, Yakima Ridge, western Umtanum Ridge, Cleman Mountain, eastern Horse Heaven Hills, Bethel Ridge, and Manastash Ridge, and finally c) the southern domain with Gordon Ridge, Columbia Hills, Toppenish Ridge, Ahtanum Ridge, and western Horse Heaven Hills. Mean anticline orientation in the northern domain it N79. $8^{\circ} \mathrm{W}$, with mean spacing between anticlines $19.6 \mathrm{~km}$. The central and southern domain ridges have mean orientations of $\mathrm{N} 71^{\circ} \mathrm{W}$ and $\mathrm{N} 79.1^{\circ} \mathrm{E}$, and mean spacings of $11.6 \mathrm{~km}$ and $27.6 \mathrm{~km}$, respectively. The CLEW structures running through the central domain demonstrate greater folding, may be due to connection to basement structures. Movement within the basalts is analogous to thin elastic plates (the basalts) moving along low friction contacts (sedimentary interbeds).

West MW. 1997. A continuation of a "pilot" study of Quaternary surface deformation, Saddle Mountains anticline, northern Pasco Basin, Washington: Final Technical Report to the U.S. Geological Survey, under Award No. 1434-HQ-97-GR-02999.

See West et al, 1994 for details. Secondary tear faults in the Gable Mountain area have displaced 13 ka ash and therefore may still be active. Fault scarps on the Smyrna Bench segment decrease in height and complexity in the western portion of the segment. Here, faults associated with the graben are likely listric and shallow. The Smyrna Bench and Saddle Gap segments are not aligned, either as a result of imbricate thrusts or a change in strike of the Saddle Mountains fault. Historical seismic activity in the north-central YFB shows earthquakes occurring in clusters and swarms. Seismicity is also concentrated in a band running parallel to and north of the Saddle Mountains, though seismicity has not been correlated with 
mapped surface faults. At the west end of Smyrna Bench, three zones of differing composition show different degrees of displacement. In these zones, displacement occurred either simultaneously or in sequence, and movement was probably localized by the relative shear strength of zone material. If rupturing occurred simultaneously, single event displacement amounts to 2.6 to $4.5 \mathrm{~m}$. Otherwise, single event displacements in the late Pleistocene to Holocene are actually less than older displacements, suggesting a decrease in slip rate. The author mentions the critical taper model, which, if applied to the YFB, would indicate that past and current activity cannot be used to predict future activity.

West MW, FX Ashland, AJ Busacca, GW Berger, and ME Shaffer. 1996. Late Quaternary deformation, Saddle Mountains anticline, south-central Washington: Geology, vol. 24, no. 12, pp. 1123-1126.

See West el al, 1994 for details. Revisions from that paper state that fault slip along thrusts active 100400 ka show $0.3 \mathrm{~m}$ displacement, and a $5 \mathrm{~m}$ scarp on Smyrna Bench is due to coseismic surface rupture. Additionally, loess flows in this area are due to recurrent movement on an active thrust. Interpretations using short-term versus long-term strain rates may result in very different conclusions, and it is recommended to use slip rates from the past few tens of thousands of years when determining probabilistic seismic hazard.

West MW, AJ Busacca, GW Berger, ME Shaffer, and FX Ashland. 1994. A "pilot" study of Quaternary surface deformation, Saddle Mountains anticline, northern Pasco Basin, Washington: Final Technical Report to the U.S. Geological Survey, under Contract 1434-94-G-2392.

The Smyrna Bench segment of the Saddle Mountains shows late Quaternary tectonic activity, as evidenced by disruption of drainage systems due to graben development. A $5 \mathrm{~m}$ tall scarp present in this area appears to be aggradational as opposed to tectonic in origin, though may be a result of landsliding due to upslope surface rupture. Because the Saddle Mountains anticline cannot accommodate more strain by folding, it must move via fault slip. Several relatively large earthquakes were recorded in the Saddle Mountains area, including an intensity IV in 1918 and a magnitude 4.4 in 1973 . Recent seismicity is not exactly aligned with mapped faults or with the fold axis. Trenching reveals both normal and thrust faults of varying age in Smyrna Bench, and it is likely that the normal faults merge with the subsurface thrust plane. In one locality, thrust faults show less than $0.5 \mathrm{~m}$ of displacement with an age of 100-400 ka, whereas nearby normal faults show greater than $6.5 \mathrm{~m}$ displacement over the last $20-40 \mathrm{kyr}$. The difference in ages indicates that there is another, active thrust fault to the north of the graben, buried by loess. Surface expression of thrust faults is often difficult to identify and can be very irregular- secondary features such as normal faults and grabens can often be used as indicators of buried thrust faults. Translating vertical displacement to slip along the fault plane gives a slip rate of at least $0.33-0.65 \mathrm{~mm} / \mathrm{yr}$, which is far greater than the estimated slip rate by Geomatrix. Thus, probabilistic seismic hazard for the Saddle Mountains fault is probably much greater than previously acknowledged, with potential earthquake magnitudes as great as 7.0.

Wong I, M Dober, M Hemphill-Haley and R Schapiro. 2002. Screening/scoping level probabilistic seismic hazard analyses: Technical Memorandum no. D-8330-2003-05 prepared for the U.S. Department of the Interior, Bureau of Reclamation.

Individual fault segments are thought to usually rupture with the same magnitude, and greater magnitude events have a longer period of recurrence. No faults within $100 \mathrm{~km}$ of the Grand Coulee and North Dams are considered seismogenic, although the Badger Mountain anticline may have been active in the early Pleistocene. For a maximum magnitude event of $\mathrm{M}=6.5$, the return period is between 10 and $50 \mathrm{kyr}$. The Columbia Plateau has a return period of 3234 yrs for events with a magnitude of at least a 6 . 
Yeats RS. 1986. Active faults related to folding. Chapter 4 in Active Tectonics: Impact on Society, Geophysics Study Committee, Geophysics Research Forum, National Research Council, pp. 6379. The National Academies Press, Washington, D.C.

All fold-and-thrust belts have an underlying décollement that slopes toward an adjacent mountain belt interior. The fold belts themselves have a wedge-shaped cross-section which tapers toward the mountain belt. Movement above the décollement takes place under pure friction sliding. Flexural-slip folding is universal to foreland fold-and-thrust belts and results in both flexural-slip and bending-moment faults. Toppenish Ridge displays bending-moment faults. In this location, the hinge of an overturned syncline has thrust faults that are here interpreted as bending-moment faults as opposed to Campbell and Bentley's (1981) interpretation that it is the surface expression of the Mill Creek décollement thrust. Thrust faults in a décollement can advance and new thrusts may form and propagate faster than regional plate convergence rates. Also, it is possible for thrust belts to accommodate most tectonic stresses in the region closest to a convergence zone, as opposed to stresses being equally distributed over the thrust belt. If a fold relatively close to a stress source is being displaced, more distal folds may be protected and become stable. Because folds move towards a fold belt's edge, that area is more likely to have actively growing folds with surface ruptures. A lack of visible displacement does not preclude active faulting, as very young faults may not have large enough displacement to be noticeable. Earthquake magnitude in a foldand-thrust belt depends partially on composition of the décollement zone- if the zone deforms plastically, magnitudes are likely to be much smaller than if the zone is thick and deforms by Coulomb friction. In the latter case, larger earthquakes could occur in the thicker region of the tapered wedge décollement.

Yeats RS. 2007. Effect of focal depth on the paleoseismology of reverse faults: Geological Society of America Abstracts with Programs.

Earthquakes originating near the brittle-plastic transition depth show little or no surface expression. Any expression present is generally manifested as broad warping and bending-moment and flexural slip faulting. YFB earthquakes are expressed as such and are therefore likely originating at the brittle-plastic transition. Recurrence intervals for YFB earthquakes reach up to tens of thousands of years. 


\section{Appendix C}

\section{Summary of Known or Suspected Quaternary Faults Within the Yakima Fold Belt}



Appendix C

Summary of Known or Suspected Quaternary Faults Within the Yakima Fold Belt

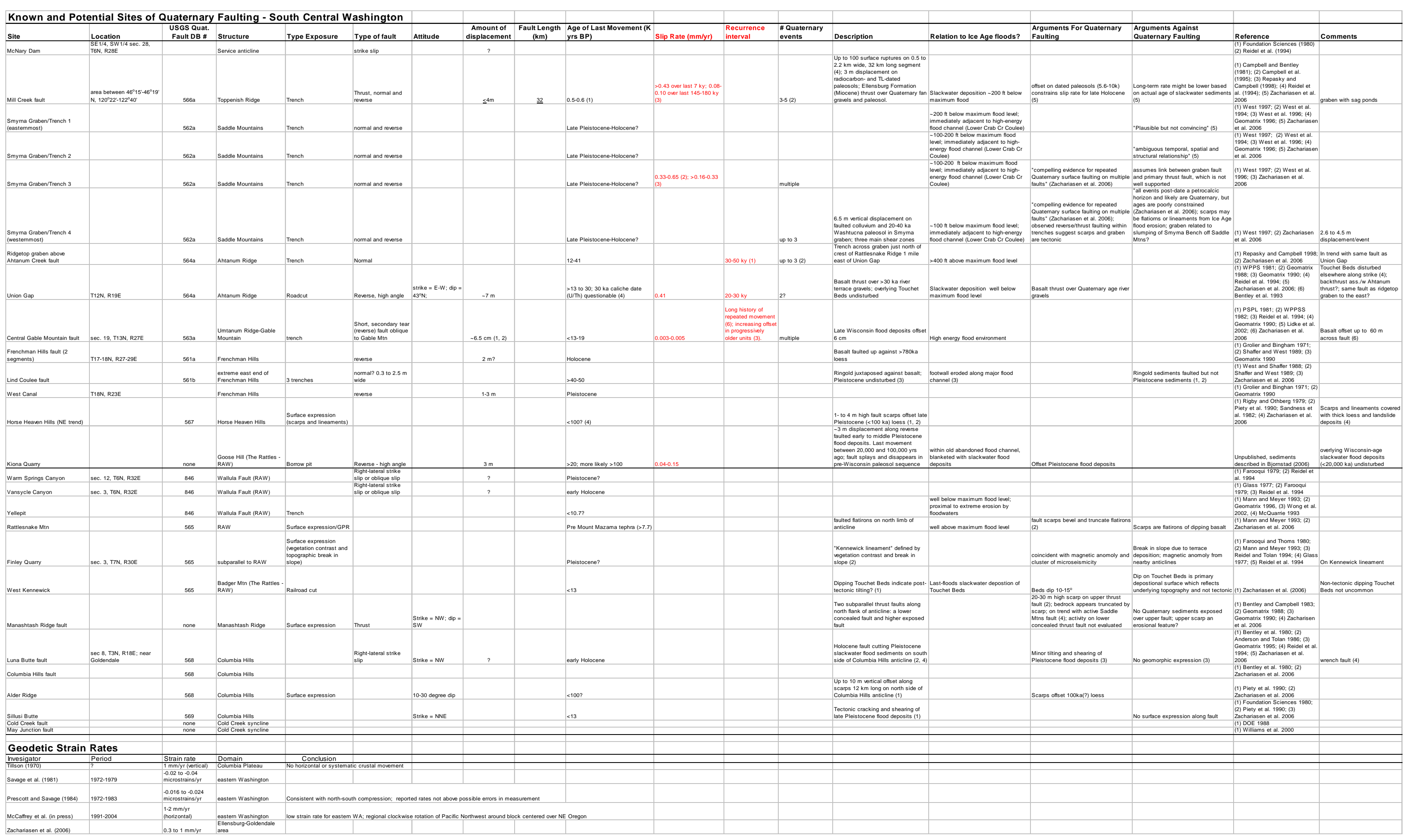






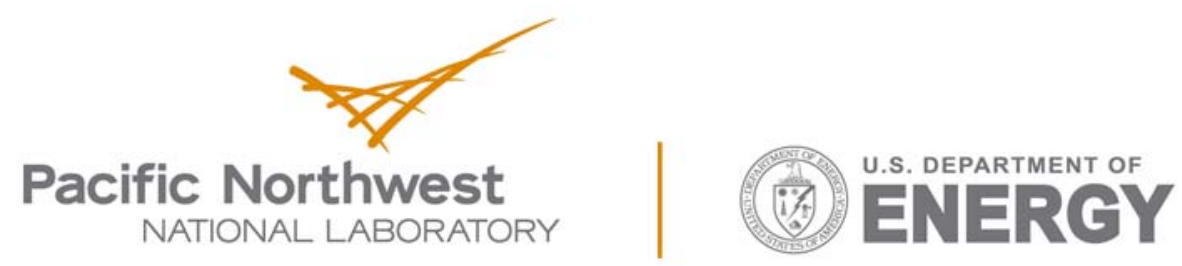

Proudly Operated by Battelle Since 1965

902 Battelle Boulevard

P.O. Box 999

Richland, WA 99352

1-888-375-PNNL (7665)

www.pnnl.gov 